\title{
Coral and Seawater Metagenomes Reveal Key Microbial Functions to Coral Health and Ecosystem Functioning Shaped at Reef Scale
}

\section{Laís Farias Oliveira Lima}

San Diego State University https://orcid.org/0000-0002-7616-3637

\section{Amanda Alker}

San Diego State University

\section{Bhavya Papudeshi}

Flinders University of South Australia: Flinders University

\section{Megan Morris}

Lawrence Livermore National Laboratory

\section{Robert Edwards}

Flinders University of South Australia: Flinders University

\section{Samantha de Putron}

Bermuda Institute of Ocean Sciences

Elizabeth Dinsdale ( $\nabla$ elizabeth.dinsdale@flinders.edu.au )

San Diego State University https://orcid.org/0000-0002-2177-203X

\section{Research}

Keywords: Host-microbiome, acclimatization, resilience, environmental change, coral reefs

Posted Date: June 15th, 2021

DOl: https://doi.org/10.21203/rs.3.rs-600995/v1

License: (c) (i) This work is licensed under a Creative Commons Attribution 4.0 International License. Read Full License 
1 Coral and seawater metagenomes reveal key microbial functions to

2 coral health and ecosystem functioning shaped at reef scale

4 Laís F. O. Lima ${ }^{1,2}$, llima@ @dsu.edu

$5 \quad$ Amanda T. Alker ${ }^{1}$, aalker@sdsu.edu

6 Bhavya Papudeshi ${ }^{3}$,npbhavya13@gmail.com

7 Megan M. Morris ${ }^{4}$, m.morris2187@gmail.com

8 Robert A. Edwards ${ }^{1,3}$, raedwards@gmail.com

9 Samantha J. de Putron ${ }^{5}$, samantha.deputron@ bios.edu

10 Elizabeth A. Dinsdale ${ }^{1,3}$, corresponding author, elizabeth.dinsdale@ @ flinders.edu.au

$12{ }^{1}$ Department of Biology, San Diego State University, San Diego, California, USA

$13{ }^{2}$ College of Biological Sciences, University of California Davis, Davis, California, USA

$14{ }^{3}$ College of Science and Engineering, Flinders University, South Australia, Australia

$15{ }^{4}$ Lawrence Livermore National Laboratory, Livermore, California, USA

$16 \quad{ }^{5}$ Bermuda Institute of Ocean Sciences, St. George's, Bermuda

\section{Keywords}

Host-microbiome, acclimatization, resilience, environmental change, coral reefs 


\section{Background}

44 The coral holobiont is comprised of a highly diverse microbial community that provides key services to corals such as protection against pathogens and nutrient cycling. The coral surface mucus layer (SML) microbiome is very sensitive to external changes and tied to ecosystem functioning, as it constitutes the direct interface between the coral host and the environment. The functional profile of microbial genes in the coral SML is underexplored and the use of shotgun metagenomics is relatively rare among coral microbiome studies. Here we investigate whether the bacterial taxonomic and functional profiles in the coral SML are shaped by the local reef zone and explore their role in coral health and ecosystem functioning.

52 Results The analysis was conducted using metagenomes and metagenome assemble genomes (MAGs) associated with the coral Pseudodiploria strigosa and the water column from two naturally distinct reef environments in Bermuda: inner patch reefs exposed to a fluctuating thermal regime and the more stable outer reefs. Our results showed that the microbial community structure is simultaneously selected by the host medium (i.e., coral SML versus water) and the local environment (i.e., inner reefs versus outer reefs), both at taxonomic and functional levels. The coral SML microbiome from inner reefs provides more gene functions that are involved in nutrient cycling (e.g., photosynthesis, phosphorus metabolism, sulfur assimilation) and that are related to higher levels of microbial activity, competition, and stress response, such as dimethylsulfoniopropionate (DMSP) breakdown. In contrast, the coral SML microbiome from outer reefs contained genes indicative of a carbohydrate-rich mucus composition found in corals exposed to less stressful temperatures and showed high proportions of microbial gene functions that play a potential role in coral disease, such as degradation of lignin-derived compounds and sulfur oxidation.

67 Conclusion

The fluctuating environment in the inner patch reefs of Bermuda could be driving a more beneficial coral SML microbiome; potentially increasing holobiont resilience to environmental changes and disease. Our results reveal microbial taxa and functions selected at reef scale in the coral SML microbiome that can leverage disease management, microbiome engineering, and microbial eco-evolutionary theories.

\section{Background}

Reef-building corals are considered model organisms to study host-associated microbiomes under environmental changes $(1,2)$. Coral colonies function as a holobiont in which the coral animal associates with a microbiome composed of endosymbiotic dinoflagellates of the family Symbiodiniaceae and a diverse community of bacteria, archaea, fungi, and viruses 
5). The coral-algae physiology depends on nutrient cycling (e.g., nitrogen and sulfur cycling) mediated by bacteria, archaea and fungi colonizing the coral holobiont (6-9). The coral surface mucous layer (SML) sustains a high abundance (106-108 cells per milliliter) and diversity of these microbial symbionts (10-13). Corals invest up to $50 \%$ of fixed carbon on mucus production $(14,15)$ for physical protection and to trap organic matter that can be consumed via heterotrophy $(16,17)$. The coral microbiome benefits from the high nitrogen content and organic matter in the SML $(9,18)$ and provides protection against coral pathogens via production of antimicrobials $(19,20)$. However, coral-associated microbial communities are sensitive to environmental changes, particularly to increased temperature and nutrient concentration, which disrupt the beneficial services provided to the holobiont (21-24). Therefore, the coral SML microbiome constitutes a direct interface between the coral host and the environment and is strongly influenced by the microbial community in the water column $(25,26)$.

The acclimatization mechanisms of the coral holobiont to changing environmental conditions are not completely understood; however, the coral microbiome is recognized as a major player. The microbial-mediated transgenerational acclimatization (MMTA) theory hypothesizes that the coral holobiont benefits from inheritable microbial taxa and/or genes acquired and/or selected in the coral microbiome when exposed to environmental changes (27). Within the coral microbiome, there is a diversity of microbial taxa with traits that potentially improve coral fitness and resilience (28). For example, the associated microbial community is a potential source of acquired heat-tolerance (29). Corals develop resilience to stress factors by associating with certain microorganisms and maintaining their "health-state" microbial taxonomic composition under stress or rapidly recovering to the "health-state" microbes after disturbances (30). Microbial functional profiles also respond to environmental gradients and can be used to identify changes in host health and ecosystem functioning (31-33). Determining which microbial taxa and functional genes are available in the surrounding environment and how they are being selected in the coral microbiome is key to provide a foundation to theories such as MMTA applied to the coral holobiont.

Coral-microbial ecology is a recent field, and the use of metagenomics is still relatively rare among coral microbiome studies (34). High-throughput sequencing has facilitated major advances in the field of microbial ecology by providing access to unculturable microbial taxa and genes via amplicon and shotgun metagenomics (35). The taxonomic composition and phylogenetic diversity of environmental microbiomes can be characterized by using markers such as the 16S rRNA gene of bacteria and archaea (36), but the metabolic potential of functional genes can only be indirectly inferred by $16 \mathrm{~S}$ rRNA gene amplicon metagenomics (37). Shotgun metagenomic sequencing does not have this caveat, since it is not restricted to marker genes (38). The use of shotgun metagenomics in coral reef research started less than 15 years ago and has focused on sequencing the microbial communities in the water surrounding corals (23, 119 underexplored. 
Here we investigate whether the microbial taxonomic and functional profiles in the coral SML are shaped by their local reef environment and explore their role in coral health and

122 ecosystem functioning.

\section{Methods}

Aim of the study. We compared the metagenomes associated with the brain coral distinct reef environments in Bermuda. The reef system in Bermuda is the most northern in the Atlantic and experiences large seasonal variations in environmental conditions (45). In addition, fine-scale variations in temperature, light, and seawater chemistry occur between the outer rim reefs at the edge of the platform and inner lagoon patch reefs (46) with the inner patch reefs historically being warmer and more thermally variable $(45,47-50)$. We showed in Lima et al. 2020 (51) that the coral SML microbiome from the inner patch reefs and the outer rim reefs in Bermuda can be modelled according to the local annual thermal profile. Here, we expand the analysis to a fine-scale taxonomic level (i.e., microbial genera and metagenome assemble genomes - MAGs) and to the functional level (i.e., SEED subsystems and pathways) in the microbial communities from the coral SML and surrounding water across these reef zones.

In situ collections. We selected $P$. strigosa as the coral host species because it is widely distributed across the Bermuda platform. The reef zones sampled were approximately $8 \mathrm{~km}$ apart (51) and $P$. strigosa is a broadcast spawner; therefore, there is a high likelihood that gene flow between the coral hosts colonizing inner and outer reefs is maintained and that the host genetics is not structured into different populations. Indeed, studies on other species have indicated high genetic exchange among reef sites in Bermuda $(52,53)$. The sampling period occurred between May $18^{\text {th }}$ and May $22^{\text {nd }}, 2017$, late spring in the northern hemisphere, when environmental conditions between the two reef zones, especially temperature, are similar. The environmental gradient assessed here are based on the knowledge that these two reef zones are exposed to different regimes on a seasonal basis, with the most striking fluctuations occurring in the winter and summer months (45-47). Therefore, we selected this period to capture a potential long-term acclimatization of the coral holobiont to their reef zones, and not their immediate response to acute temperature fluctuations. Each reef zone was replicated across three reef sites (51). The SML of $P$. strigosa was collected from six colonies (diameter, 10 to $15 \mathrm{~cm}$ ) from the inner and outer reef zones ( $n=12$ colonies total) using a two-way 50 -ml syringe filled with $0.02-\mu \mathrm{m}$ filtered seawater (51). We collected $200 \mathrm{ml}$ of coral mucus diluted in sterile seawater (four syringes applied to different parts of the colony's surface) per colony to increase DNA concentration per sample. The reef water (volume $=10 \mathrm{~L}$ per replicate) was collected about $1 \mathrm{~m}$ above the coral colonies from the inner and outer reef zones ( $n=12$ replicates total). Coral SML and water samples were pushed through a $0.22-\mu \mathrm{m}$ Sterivex filter (EMD Millipore) for DNA extraction. The collections were performed via SCUBA diving at a depth of 4 to $6 \mathrm{~m}$. A Manta2 
161 Series MultiprobeTM was be used to measure $\mathrm{pH}\left(0-14\right.$ units), water temperature $\left({ }^{\circ} \mathrm{C}\right)$,

162 chlorophyll concentrations $(\mu \mathrm{g} / \mathrm{L})$, and dissolved oxygen $(\%$ saturation and $\mathrm{mg} / \mathrm{L})$ across a $6 \mathrm{~m}$

163 depth profile at each sampling site. Our benthic survey methods were based on Atlantic and Gulf

164 Rapid Reef Assessment (AGRRA) Program protocols (54). The benthic cover was measured via

$16510-\mathrm{m}$ line transects $(\mathrm{n}=3$ per site) using the point intercept method every $10 \mathrm{~cm}(100$ points

166 total). Corals were identified at species level and the other organisms categorized in the

167 following groups: macroalgae, turf algae, crustose coralline algae, gorgonian, milleporid, sponge

168 and other.

169

170

Metagenomic analysis. Microbial DNA from the coral mucus collected on the $0.22-\mu \mathrm{m}$ Sterivex was extracted using a modified Macherey-Nagel protocol using NucleoSpin column for

172 purification. DNA was stored at $-20^{\circ} \mathrm{C}$ until quantification with Qubit (Thermo Fisher

173 Scientific) (44). The Swift kit 2 S plus (Swift Biosciences) was used for library preparation since

174 it provides good results from small amounts of input DNA, characteristic of microbial samples

175 collected from the surface of the host $(55,56)$. All samples were sequenced by the Dinsdale lab

176 on Illumina MiSeq at San Diego State University. The sequenced DNA was analyzed for quality

177 control using PrinSeq (57) before annotation. The metagenomes were annotated through MG-

178 RAST (58), using the RefSeq database for taxonomic annotations and the SEED database for

179 functional annotations. The number of sequence hits for each microbial taxon or function is

180 represented as the relative abundance by calculating the proportion of sequence hits for that

181 parameter over the total number of sequences annotated for that metagenome.

182

183

Metagenome Assembled Genomes (MAGs). Metagenome Assembled Genomes (MAGs). All

184

185 the metagenomes post quality control using Prinseq (57) were cross assembled using megahit

186

187 (59) and spades (60). To remove the redundancy in the assembled contigs, bbtools program (61) dedupe.sh script was to remove $15 \%$ of contigs that were exact duplicates. The resulting contigs were run through Metabat2 (62) and CONCOCT (63) binning tools to generate 38 MAGs and 167 MAGs respectively. DasTool (64) was run on these bins to generate 82 non-redundant set of MAGs. CheckM (65) was run on these 82 MAGs to assess the completeness and contamination within each MAG. The MAGs were annotated through PATRIC version 3.6.9 using RAST tool kit (RASTtk) (66).

Statistical analysis. Statistical analyses were conducted using PRIMER v7 plus PERMANOVA,

194 Statistical Analyses of Metagenomic profiles (STAMP) software (67), and R (R Project for

195 Statistical Computing). Significant differences in the relative abundances of microbial genera

196 and functions in the coral microbial communities sampled from inner and outer reefs were 197 identified by permutational multivariate analysis of variance (PERMANOVA) using Bray-Curtis 198 distances of normalized relative abundance obtained using a fourth-root transformation. A 199 principal coordinate analysis was created to visualize the separation of the coral microbiome 200 between inner and outer reefs. We also used PRIMER to calculate Pielou's evenness index (J') 201 and Shannon's diversity index (H') of microbial genera. The multiple comparisons of either taxa 
or functions across the four groups of metagenomes (i.e., outer coral, outer water, inner coral, and inner water) were conducted in STAMP using ANOVA/Tukey-Kramer and BenjaminiHochberg FDR corrections. We used R to test parametric assumptions of normality (ShapiroWilk's test) and homoscedasticity (Bartlett's test), and pairwise comparisons between relative abundances of gene pathways (Student's T-test).

\section{Results}

\section{Taxonomic profile}

The metagenomes associated with the coral SML of $P$. strigosa and the water column sampled from inner and outer reefs in Bermuda $(\mathrm{n}=24)$ were sequenced at high coverage, ranging from 421,976 to 1,368,678 sequence counts. Bacteria accounted for approximately $99 \%$ of the annotation (Table S1); therefore, we are only analyzing bacterial taxa and gene functions in this study. The metagenomes were assigned to four different groups (total $n=24$ with 6 metagenomes in each group) according to their host medium and location: inner reef corals, inner reef water, outer reef corals, and outer reef water. Microbial richness did not vary significantly between groups or samples, ranging from 581 to 587 bacterial genera identified, including 23 taxa unclassified at genus level, across all metagenomes. Evenness $\left(\mathrm{J}^{\prime}\right)$ of bacterial genera was slightly lower in inner reefs (coral: $0.72 \pm 0.03$, water: $0.72 \pm 0.02$ ) when compared to outer reefs (coral: $0.75 \pm 0.01$, water: $0.75 \pm 0.01$ ), which translated in a higher diversity index $\left(\mathrm{H}^{\prime}\right)$ in outer reef samples (coral: $4.78 \pm 0.06$, water: $4.80 \pm 0.08$ ) than in inner reef samples (coral: $4.56 \pm 0.17$, water: $4.59 \pm 0.11$ ).

In contrast to diversity metrics, the microbial community structure (i.e., relative abundance of taxa) was significantly different between the four groups (PERMANOVA, Pseudo$\mathrm{F}=10.8, \mathrm{p}<0.001)$. The metagenomes clustered according to the reef zone and were more similar to one another among the coral-associated samples than the water samples (Fig. 1A). Among the most abundant taxa (i.e., average relative abundance $>1 \%$ in a least one of the four groups), eight bacterial genera were significantly overrepresented according to their associated environment (Fig. 1B). The SML microbiome of corals from the inner reef zone had a greater relative abundance of the alphaproteobacterium Candidatus Pelagibacter, and of an unclassified genus, also belonging to the order Rickettsiales, compared to all other groups (ANOVA, Etasquared $=0.93, \mathrm{p}<0.001$ ). The relative abundance of cyanobacterium Synechococcus (ANOVA, Eta-squared $=0.62, \mathrm{p}<0.001$ ) was greater in the water microbiome from inner reefs compared to the microbiome from both water and coral in outer reefs (Tukey-Kramer, $\mathrm{p}<0.01$ ). This overrepresentation was also reflected in the coral SML microbiome from inner reefs compared to the coral SML microbiome from outer reefs ( $<<0.05$ ). The SML microbiome of corals from outer reefs showed a greater abundance of alphaproteobacteria Candidatus Puniceispirillum (ANOVA, Eta-squared $=0.92$, Tukey-Kramer, $\mathrm{p}<0.001)$, Ruegeria (ANOVA, Eta-squared $=$ 0.73, $\mathrm{p}<0.001$ ), and Rhodospirillum (ANOVA, Eta-squared $=0.92$, Tukey-Kramer, $\mathrm{p}<0.001$ ) compared to all groups. The coral SML microbiomes from both reef zones were enriched with 
242 gammaproteobacteria of the genus Pseudomonas (ANOVA, Eta-squared $=0.61, \mathrm{p}<0.001$ ) when 243 compared to the surrounding water microbiome from their respective local environment (Tukey244 Kramer, $\mathrm{p}<0.05$ ). In contrast, Flavobacterium had a greater representation in the microbial 245 communities from the water of both reef environments than in the microbiome associated with 246 corals from inner and outer reefs (ANOVA, Eta-squared $=0.61$, Tukey-Kramer, $\mathrm{p}<0.01$ ).
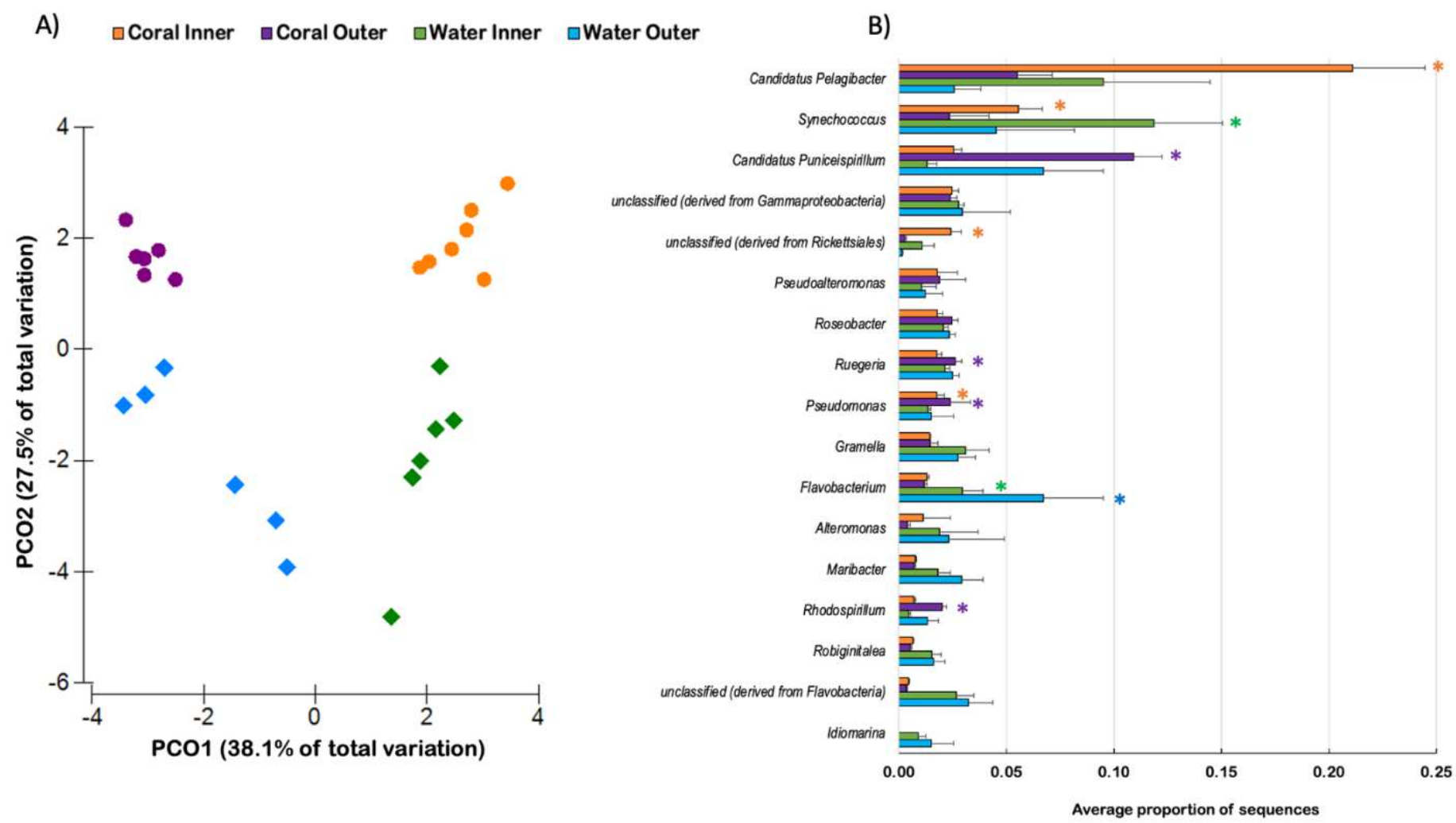

249 Figure 1. Clear differences in taxonomic make-up of the microbial community were shown using

250 a Principal Coordinate Analysis (A) based on a Bray-Curtis similarity matrix of the relative 251 abundance of bacterial genera associated with the SML microbiome of corals (circles) and the 252 water column (diamonds) from inner and outer reefs. Bacterial genera (mean $\pm \mathrm{SD}$; average 253 abundances $>1 \%$ ) showed significantly different proportions (B) according to multiple 254 comparison Tukey-Kramer tests (asterisks indicate $\mathrm{p}<0.05$ ). Metagenome Assembled Genomes (MAGs) indicated a clear separation between the 256 coral SML microbiome from inner and outer reefs (Fig. 2). A total of 82 bins were constructed, 257 and we selected eight MAGs with high levels of completeness $(53<98 \%)$ for further analysis. A 258 hierarchical clustering tree separated the bins into two major clusters, each with four MAGs, 259 including bacterial and archaeal taxa. The first cluster was formed by MAGs annotated as 260 Puniceicoccaceae (Bin 16), Synechoccocus (Bin 2), Flavobacteriaceae (Bin 1), and Candidatus 261 Pelagibacter ubique (Bin 22). The metagenomes that contributed to most to the bins in this 
cluster were samples from the SML of inner reef corals. The second cluster was comprised of

MAGs annotated as Alphaproteobacteria (Bin 116), Euryarchaeota (Bin 159), and Pseudomonas stutzeri (Bin 8 and Bin 142). The metagenomes that contributed to each of the MAGs in this cluster were majorly samples from the SML of outer reef corals.

\section{Functional profile}

The microbial communities associated with the coral SML and water column from inner and outer reefs revealed specific functional traits. Bacterial genes classified at the broadest functional categories (SEED subsystem level 1) significantly varied across the four groups (PERMANOVA, Pseudo-F = 8.49, $\mathrm{p}<0.001$ ). From a total of 26 broad functional categories, 12 were significantly overrepresented according to their associated environment (Fig. 3). The microbiome of corals from outer reefs had a greater proportional abundance of functional genes belonging to carbohydrate metabolism and to sulfur metabolism than all other groups (ANOVA, Eta-squared $=0.74$ and $0.61, \mathrm{p}<0.001$; Tukey-Kramer, $\mathrm{p}<0.05)$. In contrast, protein metabolism functional genes were significantly lower in relative abundance in the outer coral microbiome when compared to all other groups (ANOVA, Eta-squared $=0.61, \mathrm{p}<0.001$; Tukey-Kramer, $\mathrm{p}<0.01)$. Functional genes involved in metabolism of aromatic compounds were overrepresented in the water and coral microbiome of outer reefs when compared to the microbiome in the water and coral microbiome of inner reefs (ANOVA, Eta-squared $=0.84, \mathrm{p}<$ 0.001; Tukey-Kramer, $\mathrm{p}<0.001$ ).

The inner coral microbiome was overrepresented with genes involved in phosphorus metabolism and in secondary metabolism (ANOVA, Eta-squared $=0.61$ and 0.84, $\mathrm{p}<0.001$, Tukey-Kramer, $\mathrm{p}<0.01)$. Functional genes within cell division and cell cycle and cell wall and capsule were in higher abundance in the water microbiome from inner reefs compared to the microbiome from water and corals from the outer reefs and in the microbiome from inner corals compared to the outer coral microbiome (ANOVA, Eta-squared $=0.79$ and 0.72, $\mathrm{p}<0.001$; Tukey-Kramer, $\mathrm{p}<0.01)$. Photosynthesis functional genes were overrepresented in the water microbiome of inner reefs when compared to all other groups (ANOVA, Eta-squared =0.70, $<<$ 0.001; Tukey-Kramer, $\mathrm{p}<0.01$ ).

Bacterial respiration genes were overrepresented in the microbiome of corals from both reefs when compared to the microbiome in the water column from inner and outer reefs (ANOVA, Eta-squared $=0.76, \mathrm{p}<0.001$; Tukey-Kramer, $\mathrm{p}<0.01$ ). Stress response genes showed higher relative abundance in the microbiome of inner corals than in the water microbiome of inner reefs, and similarly more of stress response genes in the microbiome of outer corals when compared to the water microbiome from both reef zones (ANOVA, Etasquared $=0.67, \mathrm{p}<0.001$; Tukey-Kramer, $\mathrm{p}<0.01$ ). DNA metabolism genes were the coral microbiome from inner and outer reefs (ANOVA, Eta-squared $=0.71, \mathrm{p}<0.001$; 

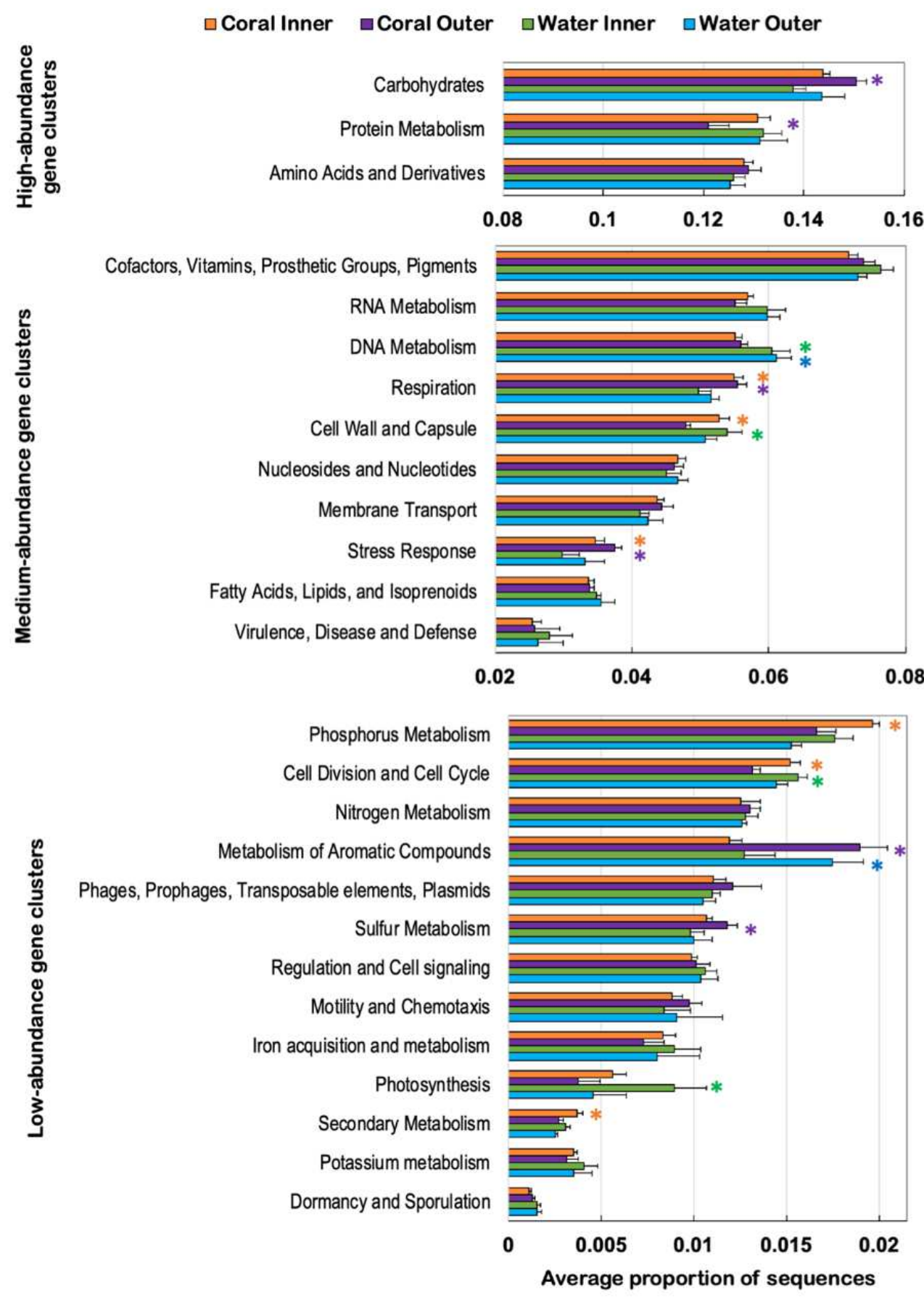

303 Figure 3. Bacterial broad functional gene categories (SEED subsystem 1) (mean \pm SD; average 304 abundances $>1 \%$ ) associated with the SML microbiome of corals, and the water column from 305 inner and outer reefs showed significantly different proportions (B) according to multiple 306 comparison Tukey-Kramer tests (asterisks indicate $\mathrm{p}<0.05$ ). 
The nine broad functional gene categories (SEED subsystem level 1) that varied significantly according to the reef zone were analyzed at a higher level of resolution (SEED

310 subsystem levels 2 and 3) to illustrate which specific functions could be under selection at reef311 zone level in the coral SML microbiome only (Fig. 4). Genes involved in central carbohydrate 312 metabolism, one-carbon metabolism, and $\mathrm{CO}_{2}$ fixation accounted for approximately $60 \%$ of the 313 total carbohydrate genes both in the inner and outer coral SML metagenomes (Fig. 4A). Protein 314 biosynthesis genes (relative abundance $=70 \%$ ) dominated the protein metabolism, followed by 315 protein degradation genes (relative abundance $=14 \%$ ) (Fig. 4B). Gram negative cell wall 316 components (relative abundance $=32 \%$ ) and capsular and extracellular polysaccharides (relative 317 abundance $=26-27 \%$ ), were dominant among cell wall and capsule genes (Fig. 4C). Phosphate 318 metabolism and transporters genes together were approximately $75 \%$ of the total phosphorus 319 metabolism, whereas genes involved in phosphorus uptake by Cyanobacteria at $12 \%$ relative 320 abundance (Fig. 4D). Within cell division and cell cycle, two cell division clusters/chromosome 321 partitioning genes were higher in inner coral SML metagenomes (relative abundance $=23 \%$ ) 322 compared to outer coral SML metagenomes (relative abundance $=19 \%$ ) (Fig. 4E). In the 323 metabolism of aromatic compounds, n-Phenylalkanoic acid degradation and anaerobic benzoate 324 genes were more represented in inner coral metagenomes (22\% in inner and $15 \%$ in outer, and $32511 \%$ in inner and $9 \%$ outer, respectively), while benzoate catabolism was higher in outer coral 326 metagenomes (6\%, compared to $4 \%$ in inner), and cathecol branch was approximately $8 \%$ in 327 both groups (Fig. 4F). Proteorhodopsin genes accounted for $30 \%$ of the photosynthesis and 328 light-harvesting complexes in outer coral metagenomes, compared to $20 \%$ in inner coral 329 abundance $=22 \%$ ) compared to the inner coral metagenomes (relative abundance $=25 \%)($ Fig. $4 \mathrm{G})$. In secondary metabolism, genes encoding auxin biosynthesis were higher in outer coral metagenomes than in the ones from inner reefs (relative abundances of $52 \%$ and $38 \%$, respectively), contrasting with alkaloid biosynthesis from L-lysine genes that were more represented in inner coral metagenomes (28\% versus $10 \%$ ). Sulfur metabolism genes showed striking differences in proportions at subsystems level 3 (Fig 4I), where sulfur oxidation genes were almost three-fold more abundant in outer coral metagenomes than in inner coral metagenomes. Because of the differences in sulfur metabolism, in the next section, we will be focusing on the specificities of sulfur pathways and their associated taxa. 

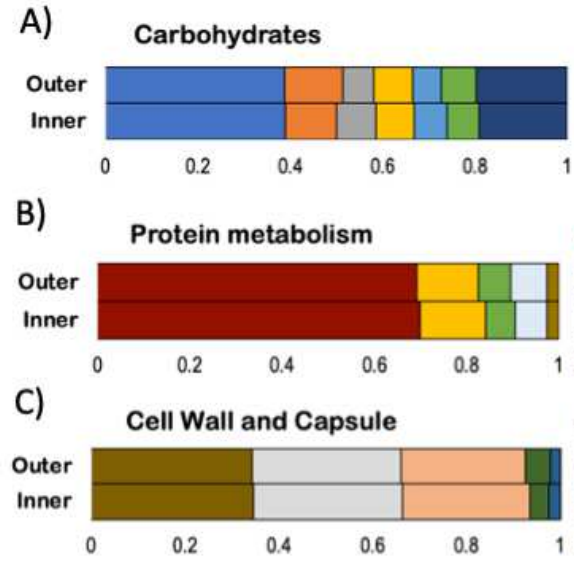

D)
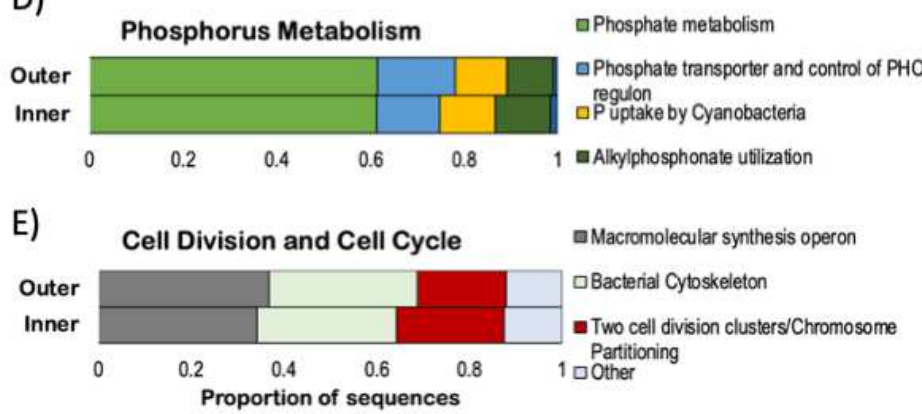

- Gram-Negative cell wall components

- Cell wall of Mycobacteria

- Gram-Posifive cell wall components
F) Metabolism of Aromatic Compounds

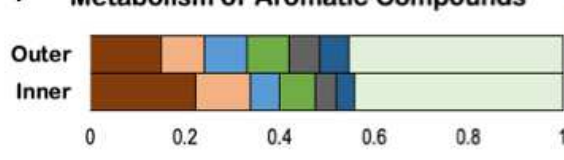

n-Phenylalkanoic acid degradation $\square$ Anaerobic benzoate metabolism a Phenylacetyl-COA catabolic pathway (core) a Catechol branch of beta-ketoadipate pathway a Phenylpropanoid compound degradation 1 Benzoate catabolism

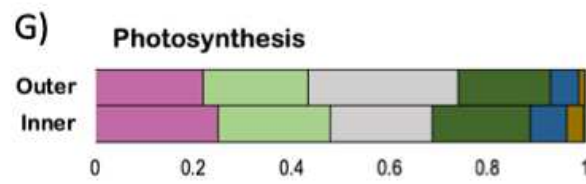

- Photosystem \|| aPhycobilisome 口Proteorhodopsin aPhotosystem I

a Photosystem II-type photosynthetic reaction center -Bacteriorhodopsin

uLight-harvesting complexes

- Capsular and Extracellular Polysacchrides
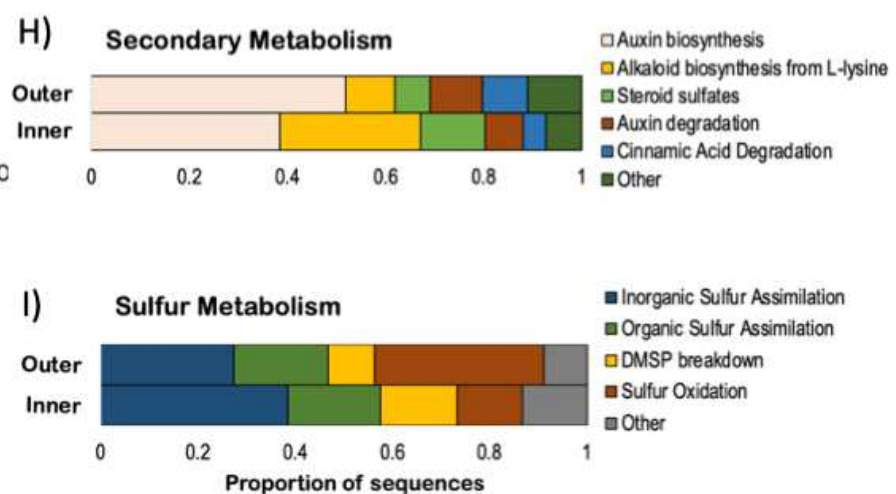

342 Figure 4. Relative abundance of bacterial functional gene subsystems (SEED subsystem 2: A - C, 343 and subsystem 3: D - I) within their respective broad functional gene category (SEED subsystem

344 1) associated with the SML microbiome of corals from inner and outer reefs.

Sulfur oxidation, inorganic sulfur assimilation, and organic sulfur assimilation (including dimethylsulfoniopropionate - DMSP breakdown) were the three major sulfur subsystems in all metagenomes, accounting for approximately $90 \%$ of total sulfur metabolism genes, but the proportions of sequences related to each subsystem varied between the two reef zones. In the microbiome of outer corals, the relative abundance of sequences from each of these subsystems were evenly distributed (sulfur oxidation $33.2 \pm 3.7 \%$; inorganic sulfur assimilation $28.3 \pm 2.5$ $\%$; and organic sulfur assimilation $29.8 \pm 1.2 \%$ ). A similar pattern was detected in the water column of outer reefs (sulfur oxidation $28.5 \pm 5.9 \%$; inorganic sulfur assimilation $34.1 \pm 4.1 \%$; and organic sulfur assimilation $26.8 \pm 1.7 \%$ ). In contrast, in the metagenomes of inner corals, sulfur oxidation is underrepresented $(12.5 \pm 3.4 \%)$, when compared to inorganic sulfur assimilation $(40.8 \pm 6.5 \%)$ and organic sulfur assimilation $(38.3 \pm 1.0 \%)$. The metagenomes from the water column of inner reefs were also low in sulfur oxidation genes $(15.7 \pm 2.1 \%)$, and high in inorganic sulfur assimilation $(38.5 \pm 3.0 \%)$ and organic sulfur assimilation $(34.0 \pm 3.1$ $\%$ ). Within the organic sulfur assimilation cluster, DMSP breakdown was highest in the SML 
361 microbiome of corals from inner reefs $(48 \pm 8.4 \%)$, followed by outer corals $(33.2 \pm 3.4 \%$ ), 362 inner water $(31.8 \pm 7.8 \%)$, and outer water $(26.5 \pm 7.6 \%)$.

363 The proportion of sequences within the sulfur metabolism cluster encoding the enzyme 364 DMSP demethylase $d m d A$ (EC. 2.1.210) was greater in the SML microbiome of corals from 365 inner reefs ( $\mathrm{T}$-test, $\mathrm{t}=5.38, \mathrm{p}=0.001 ;$ Fig. $5 \mathrm{~A}$ ), while those encoding the sulfur oxidation 366 protein $\operatorname{sox} B$ were higher in corals from outer reefs (T-test, $\mathrm{t}=-11.56, \mathrm{p}<0.001$; Fig. 5B).

367 The bacterial genera that contributed to DMSP breakdown belonged to the same five taxa 368 between inner and outer coral metagenomes, but these were represented in different proportions 369 (Fig. 5C). Roseobacter (ANOVA, Eta-squared $=0.634, \mathrm{p}<0.001$ ), Ruegeria (ANOVA, Eta370 squared $=0.625, \mathrm{p}<0.001$ ), and Dinoroseobacter (ANOVA, Eta-squared $=0.545, \mathrm{p}<0.001$ ) 371 were the main contributors to the DMSP breakdown genes in outer metagenomes, while 372 Candidatus Pelagibacter (ANOVA, Eta-squared $=0.849, \mathrm{p}<0.001$ ), and Roseovarius (ANOVA, 373 Eta-squared $=0.353, \mathrm{p}=0.042$ ) showed greater proportions in the metagenomes of inner corals.

374 Sulfur oxidation genes were encoded by 75 genera of bacteria and the twelve most abundant taxa 375 showed different relative abundances between inner and outer coral metagenomes (Fig. 4C).

376 Rhodopseudomonas (ANOVA, Eta-squared $=0.869, \mathrm{p}<0.001$ ) accounted for about one quarter

377 of all the bacterial genera encoding sulfur oxidation genes in outer coral SML, while in inner 378 corals the highest abundances were distributed more evenly across Rhodopseudomonas, 379 Ruegeria, and Roseobacter. Azorhizobium (ANOVA, Eta-squared $=0.73, \mathrm{p}<0.02$ ) was 380 overrepresented in the sulfur oxidation genes in outer coral SML, and Chlorobium (ANOVA, 381 Eta-squared $=0.63, \mathrm{p}<0.031)$ in the microbiome of inner corals. 
A)

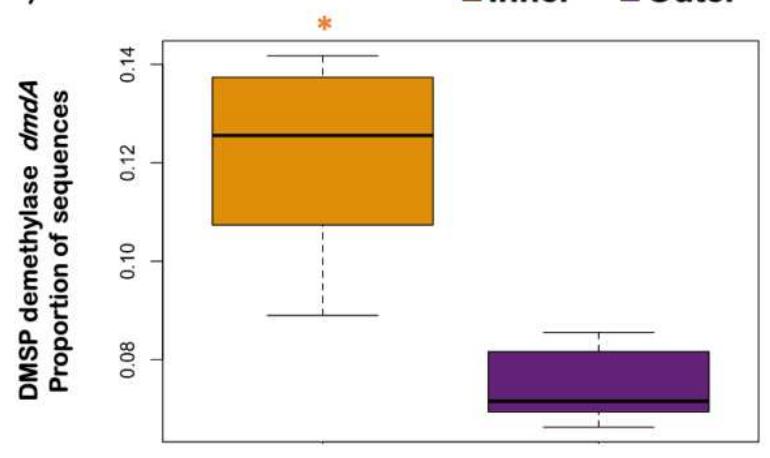

C)

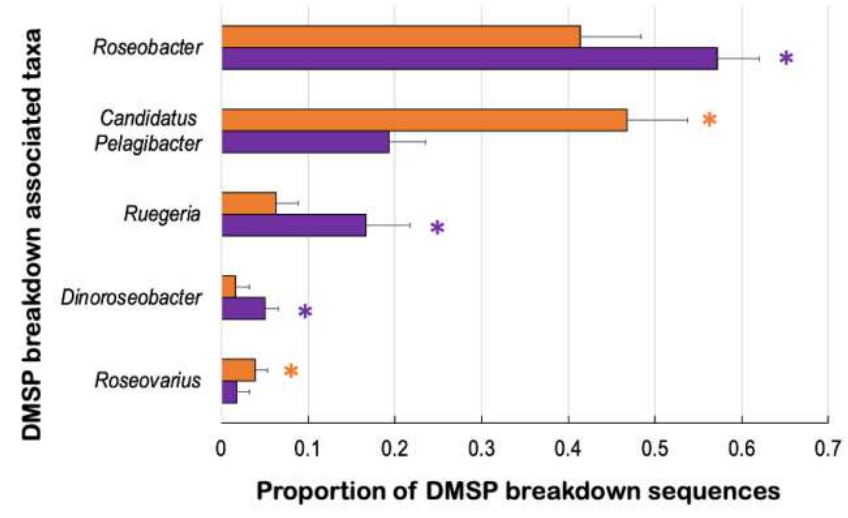

B)

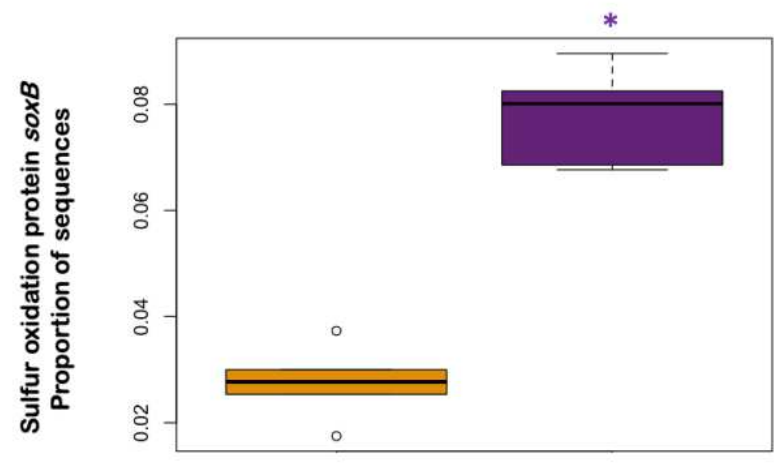

D)

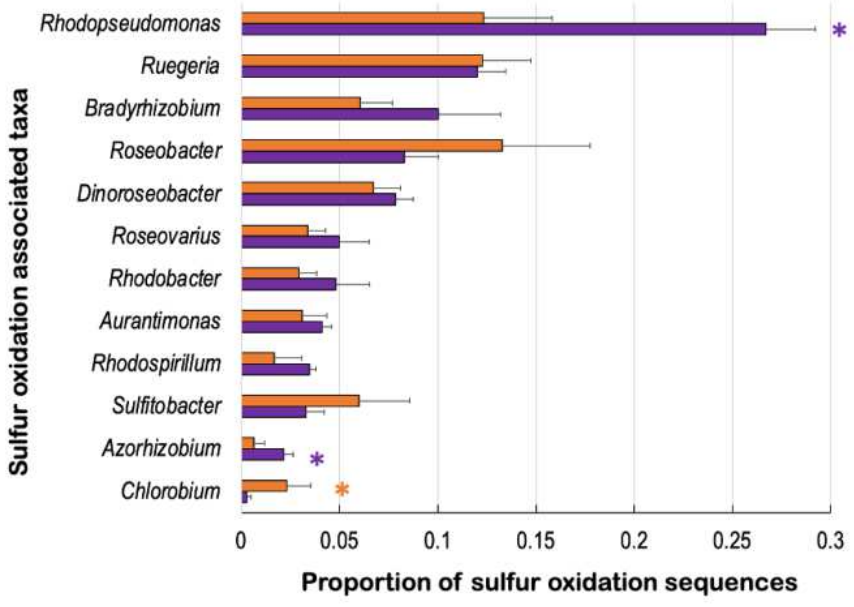

Figure 5. Sulfur metabolism gene pathways and respective taxa associated with the SML demethylase $d m d A$ genes (A) and sulfur oxidation soxB genes (B) relative to the total sulfur metabolism genes, and of bacterial genera associated to DMSP breakdown (C) and to sulfur

\section{7 oxidation (D).}

\section{Discussion}

The metagenomes associated with the SML of $P$. strigosa and water column from inner and outer reefs in Bermuda had similar taxonomic diversity and composition, corroborating that the coral SML microbiome is shaped by microbial communities in their surrounding environment $(25,26)$. However, the microbial community structure in Bermuda's reef system is simultaneously selected by the host medium (i.e., coral SML versus water) and the local environment (i.e., inner reefs versus outer reefs), both at taxonomic and functional levels. The coral SML microbiome was dominated by taxa commonly present in seawater and each reef zone had different genera filling similar niches. For example, alphaproteobacterial metabolic generalists were the most abundant genera in both reef zones, represented by SAR11 Candidatus Pelagibacter in inner corals and SAR116 Candidatus Puniceispirillum in outer corals. Among phototrophs, cyanobacterium Synechococcus was a signature genus in inner corals and 
402 key functions for coral holobiont health and ecosystem functioning; specific to each reef zone 403 (Fig. 6).

Fluctuating environment (Inner Reefs)
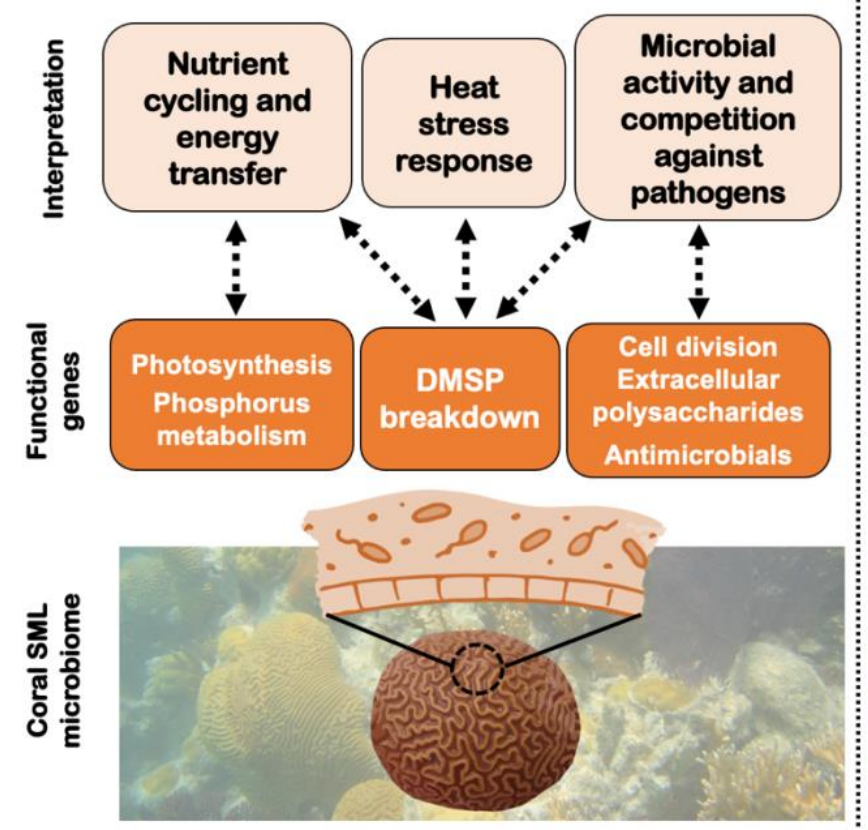

\section{Stable environment (Outer Reefs)}

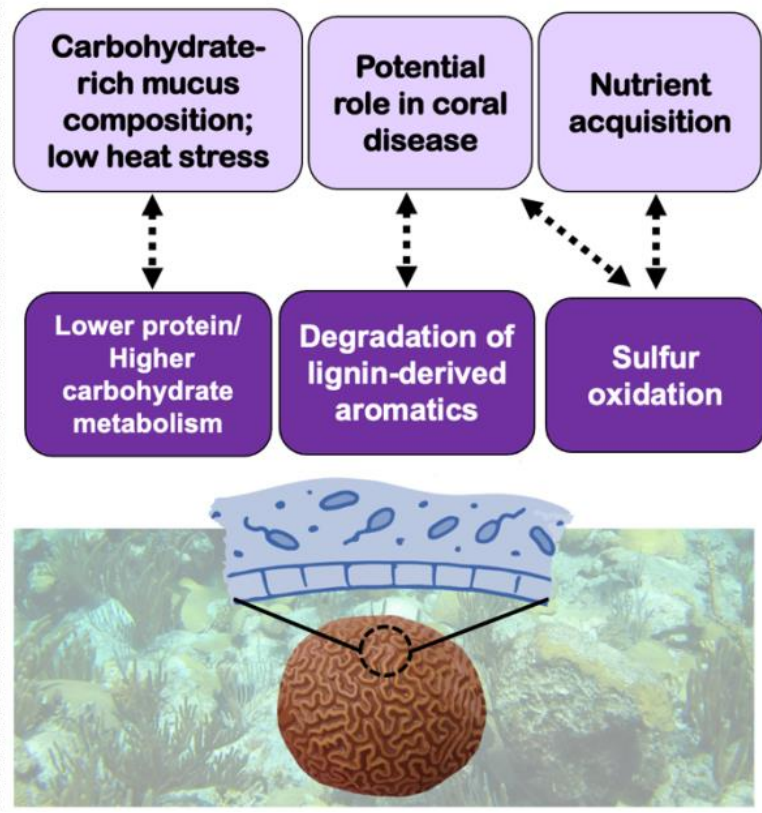

Figure 6. The functional metabolism of bacteria associated with the coral SML microbiome of $P$. strigosa varied across reef zones in Bermuda. In inner reefs, corals are exposed to a more fluctuating environment and their SML microbiome functional profile indicates that it provides more services related to nutrient cycling (e.g., carbon, phosphorus, sulfur), stress tolerance, and disease protection. In outer reefs, corals are exposed to a more stable environment and their SML microbiome is characterized by functional genes related to a mucus composition with a high carbohydrate to protein ratio (indicating low exposure to thermal stress), and involved in nutrient acquisition (i.e., taurine fermentation followed by thiosulfate oxidation) and coral disease (e.g., yellow-band and black-band diseases).

The coral SML microbiome from a fluctuating environment provides more services related to nutrient cycling, stress tolerance, and disease protection

The coral and water microbiomes from inner reefs reflect a highly productive and fluctuating system when compared to outer reefs. The overrepresentation of photosynthetic bacteria in the water column and the coral SML of inner reefs mirrored the elevated abundance of functional genes related to photosynthesis and phosphorus metabolism. Synechococcus is a main primary producer in the picoplankton, reaching the highest concentrations off Bermuda during the spring bloom (68); the same season as this study. Synechococcus was highly abundant in the metagenomes and MAGs from inner reef corals and, therefore, could be the main contributor to photosynthesis and phosphorus metabolism genes. Phosphorus metabolism was mostly comprised of genes involved in phosphate metabolism and phosphorus uptake by 
427 Cyanobacteria (e.g., Synechococcus). The coral SML is rich in phosphate when compared to the 428 water column (18); contributing to primary productivity in benthic and pelagic reef ecosystems 429 (69). The coral SML efficiently traps Synechococcus from the pelagic picoplankton, which 430 contributes to the flux of particulate organic matter (POM) from the water column to benthos 431 (70). Heat-stressed corals preferentially fed on Synechococcus to access the high nitrogen 432 content in their cells and to compensate for the loss of nitrogen from algal endosymbiont 433 Symbiodiniaceae during recovery from bleaching (71). The inner lagoon patch reefs in Bermuda 434 are exposed to greater environmental fluctuations, particularly changes in temperature (45-47, 435 51). Therefore, the high abundance of Synechococcus in the water column and in the SML of $P$. 436 strigosa could be contributing to the energy transfer from pelagic to benthic trophic levels, and to 437 the coral thermal tolerance in the inner lagoon reefs of Bermuda.

Microbial activity, growth, and competition are higher in the inner reefs than in the outer reefs, as suggested by the functional profiles from the coral SML and water column. Functional genes related to cell division and cell cycle, such as those encoding two cell division and chromosome partitioning, are in greater abundance in inner coral metagenomes. In addition, there is a high relative abundance of cell wall and capsule functional genes, including those encoding capsular and extracellular polysaccharides in the microbial communities of inner reefs. Microbial extracellular polymeric substances (EPS) play a crucial role in marine environments; increasing dissolved organic carbon (DOC) levels, binding and removing heavy metals from the water column, and influencing oxygen levels (72). Microbial growth rates in the coral SML are higher under elevated DOC levels (73); therefore, the abundance of genes related to EPS suggests an increased microbial activity in the SML of corals from inner reefs. DOC levels are also associated with larger quantities of exudates released by benthic macroalgae in coral reefs (74). Even though both reef zones showed similar coral cover; turf and macroalgae were more abundant in inner reefs (Figure S1), indicating that the DOC levels induced by macroalgae exudates could be higher in this reef zone in Bermuda. The microbial communities associated with inner corals are enriched with genes belonging to secondary metabolism, including a high relative abundance of genes encoding alkaloid biosynthesis from L-lysine. Cyanobacteria are key producers of marine alkaloids (75), which could be contributing to the high levels of these functional genes in coral metagenomes from inner reefs. Alkaloids function as antimicrobials $(76,77)$; therefore, the overrepresentation of alkaloid biosynthesis genes indicates greater microbe-microbe competition in the coral SML microbiome from inner reefs. Microbial competition and production of antimicrobial compounds offer protection against opportunistic pathogens to the coral host (77-80) and thus promoting a more beneficial SML microbiome on $P$. strigosa colonies inhabiting inner reefs compared to outer reefs.

Dimethylsulfoniopropionate (DMSP) breakdown genes (e.g., $d m d A$ ) belong to the organic sulfur assimilation subsystem and were more abundant in the SML microbiome of inner corals across all metagenomes. DMSP is a valuable component in marine environments, with high turnover rates, and is an important link between primary production and bacterial activity (81). Pelagibacter ubique, for example, exclusively assimilates sulfur from organic sources such 
as DMSP (82), and was a key taxon associated with DMSP breakdown in inner reefs. The coral metagenomes had greater proportions of Pelagibacter than the water metagenomes suggesting the coral SML is providing a DMSP-rich environment for bacterial growth. DMSP is considered an antioxidant $(83,84)$, and increased levels of this compound have been associated with stress response in the coral holobiont $(30,85,86)$. DMSP that reaches the coral SML is produced by the coral-algal symbiont (87) and the coral animal, especially under thermal stress $(6,88)$. Bacteria subsequently use this compound as a sulfur and carbon source, relying on the $d m d A$ gene to encode DMSP methyltransferase to incorporate sulfur to amino acids (e.g., methionine $(82,89)$. Sulfur as a product of DMSP breakdown can also be used by bacteria to form sulfur-based antimicrobial compounds such as tropodithietic acid (TDA), which protects the coral host by inhibiting the growth of pathogens (24). Therefore, DMSP breakdown is considered one of the main beneficial services provided by the coral microbiome to the holobiont, because it is linked both to disease protection and nutrient cycling (28). The sulfur metabolism of the microbiome of inner corals, which prioritizes sulfur assimilation and DMSP breakdown, is another indicator the coral holobiont from inner reefs are responding to a more

The coral SML microbiome from a stable environment indicates less exposure to stress, but is potentially under nutrient limitation and more prone to coral disease

The microbial functional profile in outer reefs was characterized by a carbohydratedominated metabolism, and a reduction in protein metabolism genes and is indicative of the variation of the SML composition between corals from the two reef zones. Corals secrete a polysaccharide protein lipid complex that is colonized by an abundant microbial community (16). The proportions of carbohydrates, proteins, and lipids in the coral mucus vary according to factors such as coral species (90-92), stress (93) and reef environments (92). The coral SML microbiome is strongly shaped by the mucus composition (94); therefore, the high relative abundance of microbial genes involved in carbohydrate metabolism and the loss of protein metabolism genes is consistent with corals from outer reefs producing mucus with a higher carbohydrate to protein ratio. Heat-stressed corals had an increase in protein content, and higher microbial activity, compared to healthy corals under mild temperature conditions (95). Corals from the outer reefs in Bermuda are less exposed to thermal fluctuations $(46,47,96)$ and the microbial community structure from their mucus can be modelled according to their local thermal environment (51). The reduction in protein metabolism genes and overrepresentation of carbohydrate metabolism genes suggest that the mucus composition of corals from outer reefs is characteristic of corals under low exposure to thermal stress.

Metabolism of aromatic compounds was a signature function both in the coral and water microbiomes from outer reefs. The gene encoding the enzyme muconate cycloisomerase (EC 5.5.1.1) is part of the catechol branch of beta-ketoadipate pathway and was found at lower relative abundance in the SML microbiome of inner corals $(1 \%)$, than in outer corals $(8 \%)$. The beta-ketoadipate pathway is commonly present in soil microbes, involved in the degradation 
507 lignin-derived aromatics such as cathecol to citric acid cycle intermediates (97), although lignin 508 degradation genes are found in many marine bacterial strains of

509 Pseudoalteromonas, Marinomonas, Thalassospira, among others (98). The sources of lignin that 510 is being degraded by the microbiome of outer reefs is unresolved, as this compound is

511 characteristic of vascular land plants, but lignin has recently been described to be within the cells 512 of one marine macroalga species, Calliarthron cheilosporioides (99). Interestingly, an increased 513 relative abundance of genes responsible for lignin degradation in the coral mucus microbiome 514 was associated to yellow-band disease and attributed to lysing of the coral tissue (100).

515 Therefore, the role of lignin degradation in the coral microbiome could be related to coral health 516 and needs to be further investigated.

517 Outer reef corals showed a higher abundance of total sulfur metabolism genes in their 518 SML microbiome when compared to the microbiome of inner corals. An increase in the relative 519 abundance of sulfur metabolism genes in the coral microbiome has been associated with low $\mathrm{pH}$, 520 thermal stress (23), and bleaching (101). However, the colonies were visually healthy, and the 521 environmental conditions were mild during sampling collection (Table S2). The microbiomes of 522 outer and inner corals adopted different sulfur metabolism strategies according to their local 523 environment. Sulfur oxidation was overrepresented in the outer water and coral metagenomes, in 524 comparison to metagenomes from inner reefs, which invested more in inorganic and organic sulfur assimilation. Sulfur oxidation in the coral microbiome is much less understood than sulfur assimilation and is usually studied in the context of black-band disease (BBD). BBD is one of the most virulent and widespread of all coral diseases and develops as a polymicrobial consortium dominated by cyanobacteria, sulfur- reducing and sulfur-oxidizing bacteria (SRB and SOB, respectively) that change in relative abundance across stages of infection $(102,103)$. The disease manifests as a dark microbial mat between living tissue and exposed skeleton resulting from tissue necrosis with fast progression rates (104). BBD prevalence in $P$. strigosa colonies from outer reefs was the highest across Bermuda reef zones and among other coral host species, in spite of the pristine water quality and marine protected area status (105). Sulfur oxidation genes from Rhodobacteraceae were proportionally higher in outer coral metagenomes and were identified in BBD lesions (106). However, SOB do not seem to be directly linked to BBD pathogenicity, but likely function as secondary colonizers (106). The high sulfide concentrations created by SRB and loss of oxidizers within the BBD mat are linked to coral tissue degeneration $(107,108)$. Sulfur oxidation in outer reef corals could be part of a healthy coral microbiome metabolism; related to amino acid degradation as a sulfur source to bacteria. The $\operatorname{sox} B$ gene pathway is part of the Sox enzyme complex that allows a phylogenetically diverse group of SOB to convert thiosulfate to sulfate (109) and was significantly more abundant in the outer coral SML microbiome. Thiosulfate can be a fermentation product of taurine (110). Taurine dioxygenases were present in MAGs associated with the coral microbiome, suggesting the microbes are using this amino acid as a nutrient source (111), especially in more oligotrophic waters such as in the outer reefs of Bermuda. The role of sulfur metabolism in coral health and 
disease susceptibility needs to be further studied, and the Bermuda reefs provide a natural laboratory system for coral microbiome research.

The coral SML microbiome has distinct features from the water column microbiome independent of local reef zone

The coral SML microbiome of $P$. strigosa from inner and outer reefs shared some taxonomic and functional features, despite the strong effect caused by the local reef zone. Pseudomonas was the only genus that was overrepresented in the coral SML from both reef zones in comparison to their local water microbiome. Pseudomonas stutzeri is a strong candidate to be filling that niche in corals, as it was identified by our MAGs particularly in outer reef samples. Marine strains of $P$. stutzeri have been isolated from the water column and sediment, and their major ecological roles are related to denitrification and sulfur oxidation (112). $P$. stutzeri could be playing an important nutrient cycling role in the coral SML and this relationship should be further investigated. At functional level, the coral SML microbiome showed greater proportions of respiration and stress response genes, independent of their local reef zone. The coral microbiome was dominated by heterotrophs that take advantage of the rich carbon sources in the mucus, therefore, increasing microbial respiration, i.e., oxygen consumption, when compared to the free-living, photosynthetic, and oxygen-producing microbial community in the surrounding water $(23,44)$. A greater abundance of stress response is indicative that the coral holobiont is selecting those genes, which could be a source of resilience according to the hologenome theory of evolution, if these microbial genes can be vertically transmitted (113). This is a key piece of evidence for the MMTA theory to be applied and corroborated, since it assumes that the coral holobiont benefits from inheritable microbial taxa and/or genes acquired and/or selected in the coral microbiome when exposed to environmental changes (27). Future research should investigate whether the coral holobiont is selecting microbial genes differently in response to environmental stress and whether they are passed on through generations.

\section{Conclusion}

584

Coral health has been sharply decreasing in the last two decades as coral bleaching and disease outbreaks have become more frequent worldwide, particularly correlated to rising seawater temperature (114-117). Conservation efforts to improve coral health by promoting or maintaining a beneficial microbiome (e.g., development of probiotics) depend on a detailed understanding of the dynamics of microbial taxa and functional profiles $(34,118,119)$.

Our results showed specific coral-microbial gene functions and taxa that are being selected according to the local environment, in response to primary productivity, stress, and nutrient cycles, particularly the sulfur cycle. The fluctuating environment in the inner patch reefs of Bermuda could be driving a more beneficial coral SML microbiome via local long-term acclimatization; potentially increasing holobiont resistance to thermal stress and disease. This reef zone could be a source of a coral holobiont that is more resilient to environmental changes in comparison to outer reefs. Coral restoration programs, especially when using transplantation 
of coral colonies across different areas of the reef, should design strategies that consider the trade-offs involving coral microbiome acclimatization at reef scale.

\section{Declarations}

Ethics approval and consent to participate. Not applicable. Consent for publication. Not applicable. Availability of data and materials. The metagenomic data from this study is publicly available in the SRA database as BioProject PRJNA595374 (https://www.ncbi.nlm.nih.gov/bioproject/595374) and in MG-RAST as public study SDSU_BIOS_2017 (mgp81589; https://www.mg-rast.org/linkin.cgi?project=mgp81589). Competing interests. The authors declare that they have no competing interests. Funding. We thank San Diego State University (SDSU)/University of California, Davis (UCD), Joint Doctoral Program in Ecology at SDSU/UCD, SDSU Graduate Travel Awards, and the Bermuda Institute of Science (BIOS) Grant-in-Aid Sydney L. Wright and Wolfgang Sterrer Fellowships for supporting Ph.D. candidates L.F.O.L. and A.T.A. with travel costs and research expenses at BIOS. L.F.O.L. was also supported with a graduate student scholarship awarded by S. Lo \& B. Billings Global Shark Research and Conservation fund. The funders had no role in study design, data collection and interpretation, or the decision to submit the work for publication.

Authors' contributions. L.F.O.L. designed the study, conducted sampling in situ, processed samples for metagenomic sequencing, analyzed the data, and wrote the manuscript. A.T.A. conducted sampling in situ, processed samples for metagenomic sequencing, and edited the manuscript. B.P. generated the metagenome assemble genomes and edited the manuscript. M.M.M. processed samples for metagenomic sequencing and edited the manuscript. R.A.E. conducted sampling in situ and edited the manuscript. S.J.P. helped to design the study, conducted sampling in situ, and edited the manuscript. E.A.D. designed the study, conducted sampling in situ, processed samples for metagenomic sequencing, and was a major contributor in writing the manuscript. All authors read and approved the final manuscript. Acknowledgements. We thank San Diego State University (SDSU)/University of California, Davis (UCD), Joint Doctoral Program in Ecology at SDSU/UCD, SDSU Graduate Travel Awards, and the Bermuda Institute of Science (BIOS) Grant-in-Aid Sydney L. Wright and Wolfgang Sterrer Fellowships for supporting Ph.D. candidates L.F.O.L. and A.T.A. with travel costs and research expenses at BIOS. L.F.O.L. was also supported with a graduate student scholarship awarded by S. Lo \& B. Billings Global Shark Research and Conservation fund. We thank Dr. J.B. Raina for providing insightful comments on sulfur oxidation in the coral

\section{Supplemental Material}


627 Table S1. Metagenomic sequences coverage and annotation hits through MG-RAST (as of April $\left.6288^{\text {th }}, 2021\right)$.

\begin{tabular}{llll} 
Metagenome name & Sample ID & $\begin{array}{l}\text { Total number of } \\
\text { sequences }\end{array}$ & $\begin{array}{l}\text { Bacterial genera } \\
\text { sequence hits }\end{array}$ \\
\hline Inner_Reef_1_AA & mgs602127 & 932,522 & 409,892 \\
Inner_Reef_1_LL & mgs602130 & $1,264,982$ & 539,254 \\
Inner_Reef_1_water_1 & mgs602169 & 860,221 & 522,241 \\
Inner_Reef_1_water_2 & mgs602172 & 780,980 & 556,559 \\
Inner_Reef_2_AA & mgs602133 & $1,115,369$ & 473,425 \\
Inner_Reef_2_water_1 & mgs602175 & 897,812 & 594,281 \\
Inner_Reef_2_water_2 & mgs602178 & 968,692 & 746,806 \\
Inner_Reef_3_AA2 & mgs602145 & 626,624 & 262,136 \\
Inner_Reef_3_LL1 & mgs602142 & 898,828 & 354,127 \\
Inner_Reef_3_LL2 & mgs602148 & 870,627 & 343,187 \\
Inner_Reef_3_water_1 & mgs602181 & 642,681 & 478,392 \\
Inner_Reef_3_water_2 & mgs602184 & 752,643 & 584,613 \\
Outer_Reef_1_AA & mgs602151 & 921,996 & 341,979 \\
Outer_Reef_1_LL & mgs602154 & 864,577 & 609,245 \\
Outer_Reef_1_water_1 & mgs602187 & 985,985 & 610,602 \\
Outer_Reef_1_water_2 & mgs602190 & $1,221,790$ & 705,749 \\
Outer_Reef_2_AA & mgs602157 & 858,085 & 548,099 \\
Outer_Reef_2_LL & mgs602160 & $1,368,678$ & 906,029 \\
Outer_Reef_2_water_1 & mgs602193 & $1,025,086$ & 759,119 \\
Outer_Reef_2_water_2 & mgs602196 & 526,746 & 455,237 \\
Outer_Reef_3_AA & mgs602163 & 646,510 & 287,792 \\
Outer_Reef_3_LL & mgs602166 & 684,623 & 486,791 \\
Outer_Reef_3_water_1 & mgs602199 & 421,976 & 250,062 \\
Outer_Reef_3_water_2 & mgs602202 & 657,501 & 424,819 \\
& & &
\end{tabular}

631 Table S2. Environmental parameters (mean \pm SD) in the water column (4-5m depth) of inner and 632 outer reefs of Bermuda.

\begin{tabular}{|c|c|c|c|c|c|}
\hline Reef Zone & $\begin{array}{l}\text { Temperature } \\
\left({ }^{\circ} \mathrm{C}\right)\end{array}$ & $\mathrm{pH}$ & $\begin{array}{l}\text { Chlorophyll-a } \\
\text { concentration } \\
(\mu \mathrm{g} / \mathrm{L})\end{array}$ & $\begin{array}{l}\text { Dissolved } \\
\text { Oxygen } \\
(\mathrm{mg} / \mathrm{L})\end{array}$ & $\begin{array}{l}\text { Dissolved } \\
\text { Oxygen } \\
\text { Saturation }(\%)\end{array}$ \\
\hline Inner Reefs & $23.83 \pm 0.21$ & $8.27 \pm 0.03$ & $1.79 \pm 0.23$ & $7.22 \pm 0.04$ & $106.53 \pm 0.53$ \\
\hline Outer Reefs & $23.15 \pm 0.33$ & $8.27 \pm 0.03$ & $1.32 \pm 0.06$ & $7.30 \pm 0.34$ & $106.53 \pm 5.44$ \\
\hline
\end{tabular}




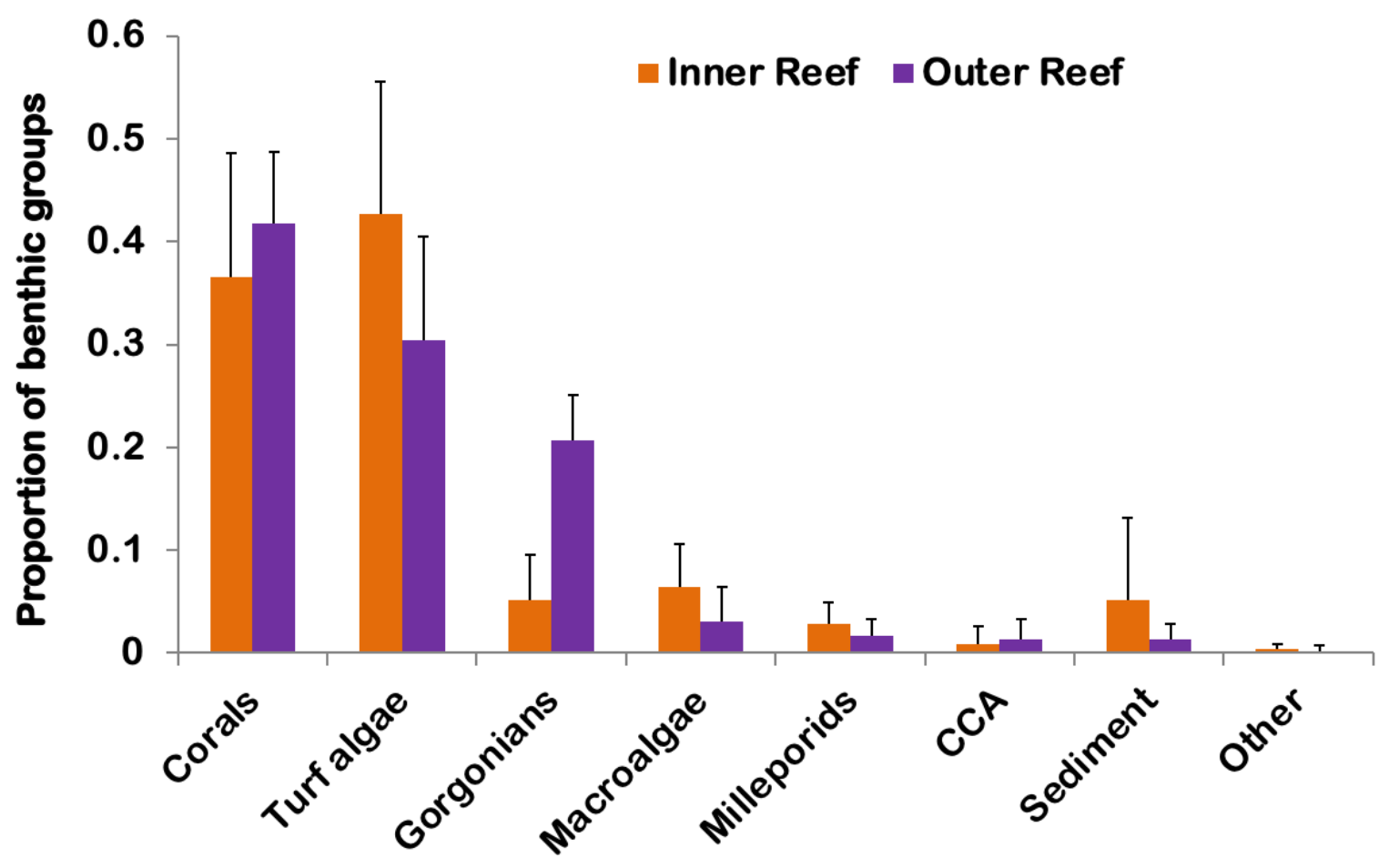

633

Figure S1. Benthic coverage (mean $\pm \mathrm{SD}$ ) of inner and outer reefs of Bermuda.

\section{References}

1. Apprill A. 2017. Marine Animal Microbiomes: Toward Understanding Host-Microbiome Interactions in a Changing Ocean. Front Mar Sci 4:1-9.

2. Zaneveld JR, McMinds R, Thurber RV. 2017. Stress and stability: Applying the Anna Karenina principle to animal microbiomes. Nat Microbiol 2.

3. Rohwer F, Seguritan V, Azam F, Knowlton N. 2002. Diversity and distribution of coralassociated bacteria. Mar Ecol Prog Ser 243:1-10.

4. Grottoli AG, Rodrigues LJ, Palardy JE. 2006. Heterotrophic plasticity and resilience in bleached corals. Nature 440:1186.

5. Tremblay P, Grover R, Maguer JF, Legendre L, Ferrier-Pagès C. 2012. Autotrophic carbon budget in coral tissue: a new 13C-based model of photosynthate translocation. J Exp Biol 215:1384-1393.

6. Raina JB, Tapiolas DM, Forêt S, Lutz A, Abrego D, Ceh J, Seneca FO, Clode PL, Bourne DG, Willis BL, Motti CA. 2013. DMSP biosynthesis by an animal and its role in coral thermal stress response. Nature 502:677-680.

7. Wegley L, Edwards R, Rodriguez-Brito B, Liu H, Rohwer F. 2007. Metagenomic analysis of the microbial community associated with the coral Porites astreoides. Environ Microbiol 9:2707-2719.

8. Siboni N, Ben-Dov E, Sivan A, Kushmaro A. 2008. Global distribution and diversity of coral-associated Archaea and their possible role in the coral holobiont nitrogen cycle. Environ Microbiol 10:2979-2990.

9. Rädecker N, Pogoreutz C, Voolstra CR, Wiedenmann J, Wild C. 2015. Nitrogen cycling 
in corals: the key to understanding holobiont functioning? Trends Microbiol 23:490-497.

10. Sharon G, Rosenberg E. 2008. Bacterial growth on coral mucus. Curr Microbiol 56:481488.

11. Koren O, Rosenberg E. 2006. Bacteria associated with mucus and tissues of the coral Oculina patagonica in summer and winter. Appl Environ Microbiol 72:5254-5259.

12. Ainsworth T, Krause L, Bridge T, Torda G, Raina J-B, Zakrzewski M, Gates RD, PadillaGamiño JL, Spalding HL, Smith C, Woolsey ES, Bourne DG, Bongaerts P, HoeghGuldberg O, Leggat W. 2015. The coral core microbiome identifies rare bacterial taxa as ubiquitous endosymbionts. Isme J 9:2261.

13. Garren M, Azam F. 2012. Corals shed bacteria as a potential mechanism of resilience to organic matter enrichment. ISME J 6:1159-1165.

14. Crossland CJ, Barnes DJ, Borowitzka MA. 1980. Diurnal lipid and mucus production in the staghorn coral Acropora acuminata. Mar Biol 60:81-90.

15. Crossland CJ. 1987. In situ release of mucus and DOC-lipid from the corals Acropora variabilis and Stylophora pistillata in different light regimes. Coral reefs 6:35-42.

16. Brown BE, Bythell JC. 2005. Perspectives on mucus secretion in reef corals. Mar Ecol Prog Ser 296:291-309.

17. Wild C, Huettel M, Klueter A, Kremb SG, Rasheed MYM, Jørgensen BB. 2004. Coral mucus functions as an energy carrier and particle trap in the reef ecosystem. Nature 428:66-70.

18. Wild C, Woyt H, Huettel M. 2005. Influence of coral mucus on nutrient fluxes in carbonate sands. Mar Ecol Prog Ser 287:87-98.

19. Krediet CJ, Ritchie KB, Paul VJ, Teplitski M. 2013. Coral-associated micro-organisms and their roles in promoting coral health and thwarting diseases. Proc R Soc London B Biol Sci 280:20122328.

20. Ritchie KB. 2006. Regulation of microbial populations by coral surface mucus and mucus-associated bacteria. Mar Ecol Prog Ser 322:1-14.

21. Vega Thurber RL, Burkepile DE, Fuchs C, Shantz AA, Mcminds R, Zaneveld JR. 2014. Chronic nutrient enrichment increases prevalence and severity of coral disease and bleaching. Glob Chang Biol 20:544-554.

22. Zaneveld JR, Burkepile DE, Shantz AA, Pritchard CE, McMinds R, Payet JP, Welsh R, Correa AMS, Lemoine NP, Rosales S, Fuchs C, Maynard JA, Thurber RV. 2016. Overfishing and nutrient pollution interact with temperature to disrupt coral reefs down to microbial scales. Nat Commun 7:1-12.

23. Thurber RV, Willner-Hall D, Rodriguez-Mueller B, Desnues C, Edwards RA, Angly F, Dinsdale E, Kelly L, Rohwer F. 2009. Metagenomic analysis of stressed coral holobionts. Environ Microbiol 11:2148-2163.

24. Raina J-B, Tapiolas D, Motti CA, Foret S, Seemann T, Tebben J, Willis BL, Bourne DG. 2016. Isolation of an antimicrobial compound produced by bacteria associated with reefbuilding corals. PeerJ 4:e2275.

25. Apprill A, Weber LG, Santoro AE. 2016. Distinguishing between Microbial Habitats Unravels Ecological Complexity in Coral Microbiomes. mSystems 1:e00143-16.

26. Pollock FJ, McMinds R, Smith S, Bourne DG, Willis BL, Medina M, Thurber RV, Zaneveld JR. 2018. Coral-associated bacteria demonstrate phylosymbiosis and cophylogeny. Nat Commun 9:4921.

27. Webster NS, Reusch TBH. 2017. Microbial contributions to the persistence of coral reefs. 
ISME J 11:2167-2174.

28. Peixoto RS, Rosado PM, Leite DC de A, Rosado AS, Bourne DG. 2017. Beneficial microorganisms for corals (BMC): Proposed mechanisms for coral health and resilience. Front Microbiol 8.

29. Ziegler M, Seneca FO, Yum LK, Palumbi SR, Voolstra CR. 2017. Bacterial community dynamics are linked to patterns of coral heat tolerance. Nat Commun 8:1-8.

30. Garren M, Raymundo L, Guest J, Harvell CD, Azam F. 2009. Resilience of coralassociated bacterial communities exposed to fish farm effluent. PLoS One 4.

31. Shade A, Peter H, Allison SD, Baho DL, Berga M, Bürgmann H, Huber DH, Langenheder S, Lennon JT, Martiny JBH, Matulich KL, Schmidt TM, Handelsman J. 2012. Fundamentals of microbial community resistance and resilience. Front Microbiol 3:1-19.

32. Widder S, Allen RJ, Pfeiffer T, Curtis TP, Wiuf C, Sloan WT, Cordero OX, Brown SP, Momeni B, Shou W, Kettle H, Flint HJ, Haas AF, Laroche B, Kreft JU, Rainey PB, Freilich S, Schuster S, Milferstedt K, Van Der Meer JR, Grobkopf T, Huisman J, Free A, Picioreanu C, Quince C, Klapper I, Labarthe S, Smets BF, Wang H, Soyer OS, Allison SD, Chong J, Lagomarsino MC, Croze OA, Hamelin J, Harmand J, Hoyle R, Hwa TT, Jin Q, Johnson DR, de Lorenzo V, Mobilia M, Murphy B, Peaudecerf F, Prosser JI, Quinn RA, Ralser M, Smith AG, Steyer JP, Swainston N, Tarnita CE, Trably E, Warren PB, Wilmes P. 2016. Challenges in microbial ecology: Building predictive understanding of community function and dynamics. ISME J 10:2557-2568.

33. Kelly LW, Williams GJ, Barott KL, Carlson CA, Dinsdale EA, Edwards RA, Haas AF, Haynes M, Lim YW, McDole T, Nelson CE, Sala E, Sandin SA, Smith JE, Vermeij MJA, Youle M, Rohwer F. 2014. Local genomic adaptation of coral reef-associated microbiomes to gradients of natural variability and anthropogenic stressors. Proc Natl Acad Sci 111:10227-10232.

34. van Oppen MJH, Blackall LL. 2019. Coral microbiome dynamics, functions and design in a changing world. Nat Rev Microbiol 17:557-567.

35. Streit WR, Schmitz RA. 2004. Metagenomics-the key to the uncultured microbes. Curr Opin Microbiol 7:492-498.

36. Case RJ, Boucher Y, Dahllöf I, Holmström C, Doolittle WF, Kjelleberg S. 2007. Use of 16S rRNA and rpoB genes as molecular markers for microbial ecology studies. Appl Environ Microbiol 73:278-288.

37. Langille MGI, Zaneveld J, Caporaso JG, McDonald D, Knights D, Reyes JA, Clemente JC, Burkepile DE, Thurber RLV, Knight R. 2013. Predictive functional profiling of microbial communities using 16S rRNA marker gene sequences. Nat Biotechnol 31:814.

38. Brumfield KD, Huq A, Colwell RR, Olds JL, Leddy MB. 2020. Microbial resolution of whole genome shotgun and $16 \mathrm{~S}$ amplicon metagenomic sequencing using publicly available NEON data. PLoS One 15:e0228899.

39. Silveira CB, Cavalcanti GS, Walter JM, Silva-Lima AW, Dinsdale EA, Bourne DG, Thompson CC, Thompson FL. 2017. Microbial processes driving coral reef organic carbon flow. FEMS Microbiol Rev 41:575-595.

40. Coutinho FH, Silveira CB, Gregoracci GB, Thompson CC, Edwards RA, Brussaard CPD, Dutilh BE, Thompson FL. 2017. Marine viruses discovered via metagenomics shed light on viral strategies throughout the oceans. Nat Commun 8:1-12.

41. Walsh K, Haggerty JM, Doane MP, Hansen JJ, Morris MM, Moreira APB, de Oliveira L, Leomil L, Garcia GD, Thompson F, Dinsdale EA. 2017. Aura-biomes are present in the 
water layer above coral reef benthic macro-organisms. PeerJ 5:e3666.

42. Haas AF, Fairoz MFM, Kelly LW, Nelson CE, Dinsdale EA, Edwards RA, Giles S, Hatay M, Hisakawa N, Knowles B, Lim YW, Maughan H, Pantos O, Roach TNF, Sanchez SE, Nat Microbiol 1:1-7.

43. Kelly LW, Nelson CE, Haas AF, Naliboff DS, Calhoun S, Carlson CA, Edwards RA, Fox MD, Hatay M, Johnson MD, Kelly ELA, Lim YW, Macherla S, Quinlan ZA, Silva GGZ, Vermeij MJA, Zgliczynski B, Sandin SA, Smith JE, Rohwer F. 2019. Diel population and functional synchrony of microbial communities on coral reefs. Nat Commun 10:1691.

44. Dinsdale EA, Pantos O, Smriga S, Edwards RA, Angly F, Wegley L, Hatay M, Hall D, Brown E, Haynes M. 2008. Microbial ecology of four coral atolls in the Northern Line Islands. PLoS One 3:e1584.

45. Smith SR, Sarkis S, Murdoch TJT, Croquer A, Bates NR, Johnson RJ, Putron S De, Andersson AJ. 2013. Coral Reefs of the United Kingdom Overseas Territories 4.

46. Courtney TA, Lebrato M, Bates NR, Collins A, de Putron SJ, Garley R, Johnson R, Molinero JC, Noyes TJ, Sabine CL, Andersson AJ. 2017. Environmental controls on modern scleractinian coral and reef-scale calcification. Sci Adv 3.

47. de Putron SJ, Smith SR. 2011. Planula release and reproductive seasonality of the scleractinian coral Porites astreoides in Bermuda, a high-latitude reef. Bull Mar Sci 87:7590.

48. Courtney TA, Kindeberg T, Andersson AJ. 2020. Coral calcification responses to the North Atlantic Oscillation and coral bleaching in Bermuda. PLoS One 15:e0241854.

49. de Putron SJ, Lawson JM, White KQL, Costa MT, Geronimus MVB, MacCarthy A. 2017. Variation in larval properties of the Atlantic brooding coral Porites astreoides between different reef sites in Bermuda. Coral Reefs 36:383-393.

50. Wong KH, Goodbody-Gringley G, de Putron SJ, Becker DM, Chequer A, Putnam HM. 2021. Brooded coral offspring physiology depends on the combined effects of parental press and pulse thermal history. Glob Chang Biol.

51. Lima LFO, Weissman M, Reed M, Papudeshi B, Alker AT, Morris MM, Edwards RA, de Putron SJ, Vaidya NK, Dinsdale EA. 2020. Modeling of the coral microbiome: the influence of temperature and microbial network. MBio 11.

52. Serrano XM, Baums IB, Smith TB, Jones RJ, Shearer TL, Baker AC. 2016. Long distance dispersal and vertical gene flow in the Caribbean brooding coral Porites astreoides. Sci Rep 6:1-12.

53. Serrano X, Baums IB, O'reilly K, Smith TB, Jones RJ, Shearer TL, Nunes FLD, Baker AC. 2014. Geographic differences in vertical connectivity in the $C$ aribbean coral $M$ ontastraea cavernosa despite high levels of horizontal connectivity at shallow depths. Mol Ecol 23:4226-4240.

54. Lang JC, Marks KW, Kramer PR, Ginsburg RN. 2015. Atlantic \& Gulf Rapid Reef Assessment (AGRRA).

55. Doane MP, Haggerty JM, Kacev D, Papudeshi B, Dinsdale EA. 2017. The skin microbiome of the common thresher shark (Alopias vulpinus) has low taxonomic and gene function $\beta$-diversity. Environ Microbiol Rep 9:357-373.

56. Cavalcanti GS, Shukla P, Morris M, Ribeiro B, Foley M, Doane MP, Thompson CC, Edwards MS, Dinsdale EA, Thompson FL. 2018. Rhodoliths holobionts in a changing ocean: Host-microbes interactions mediate coralline algae resilience under ocean 
57. Schmieder R, Edwards R. 2011. Quality control and preprocessing of metagenomic datasets. Bioinformatics 27:863-864.

58. Meyer F, Bagchi S, Chaterji S, Gerlach W, Grama A, Harrison T, Paczian T, Trimble WL, Wilke A. 2019. MG-RAST version 4-lessons learned from a decade of low-budget ultrahigh-throughput metagenome analysis. Brief Bioinform 20:1151-1159.

59. Li D, Liu C-M, Luo R, Sadakane K, Lam T-W. 2015. MEGAHIT: an ultra-fast singlenode solution for large and complex metagenomics assembly via succinct de Bruijn graph. Bioinformatics 31:1674-1676.

60. Prjibelski A, Antipov D, Meleshko D, Lapidus A, Korobeynikov A. 2020. Using SPAdes de novo assembler. Curr Protoc Bioinforma 70:e102.

61. Bushnell B, Rood J, Singer E. 2017. BBMerge-Accurate paired shotgun read merging via overlap. PLoS One 12:e0185056.

62. Kang DD, Li F, Kirton E, Thomas A, Egan R, An H, Wang Z. 2019. MetaBAT 2: an adaptive binning algorithm for robust and efficient genome reconstruction from metagenome assemblies. PeerJ 7:e7359.

63. Alneberg J, Bjarnason BS, De Bruijn I, Schirmer M, Quick J, Ijaz UZ, Lahti L, Loman NJ, Andersson AF, Quince C. 2014. Binning metagenomic contigs by coverage and composition. Nat Methods 11:1144-1146.

64. Sieber CMK, Probst AJ, Sharrar A, Thomas BC, Hess M, Tringe SG, Banfield JF. 2018. Recovery of genomes from metagenomes via a dereplication, aggregation and scoring strategy. Nat Microbiol 3:836-843.

65. Parks DH, Imelfort M, Skennerton CT, Hugenholtz P, Tyson GW. 2015. CheckM: assessing the quality of microbial genomes recovered from isolates, single cells, and metagenomes. Genome Res 25:1043-1055.

66. Brettin T, Davis JJ, Disz T, Edwards RA, Gerdes S, Olsen GJ, Olson R, Overbeek R, Parrello B, Pusch GD. 2015. RASTtk: a modular and extensible implementation of the RAST algorithm for building custom annotation pipelines and annotating batches of genomes. Sci Rep 5:1-6.

67. Parks DH, Tyson GW, Hugenholtz P, Beiko RG. 2014. STAMP: statistical analysis of taxonomic and functional profiles. Bioinformatics 30:3123-3124.

68. DuRand MD, Olson RJ, Chisholm SW. 2001. Phytoplankton population dynamics at the Bermuda Atlantic Time-series station in the Sargasso Sea. Deep Sea Res Part II Top Stud Oceanogr 48:1983-2003.

69. Huettel M, Wild C, Gonelli S. 2006. Mucus trap in coral reefs: Formation and temporal evolution of particle aggregates caused by coral mucus. Mar Ecol Prog Ser 307:69-84.

70. Naumann MS, Richter C, el-Zibdah M, Wild C. 2009. Coral mucus as an efficient trap for picoplanktonic cyanobacteria: implications for pelagic-benthic coupling in the reef ecosystem. Mar Ecol Prog Ser 385:65-76.

71. Meunier V, Bonnet S, Pernice M, Benavides M, Lorrain A, Grosso O, Lambert C, Houlbrèque F. 2019. Bleaching forces coral's heterotrophy on diazotrophs and Synechococcus. ISME J 13:2882-2886.

72. Bhaskar P V, Bhosle NB. 2005. Microbial extracellular polymeric substances in marine biogeochemical processes. Curr Sci 88:45-53.

73. Kline DI, Kuntz NM, Breitbart M, Knowlton N, Rohwer F. 2006. Role of elevated organic carbon levels and microbial activity in coral mortality. Mar Ecol Prog Ser 314:119-125. 
74. Haas AF, Nelson CE, Kelly LW, Carlson CA, Rohwer F, Leichter JJ, Wyatt A, Smith JE. 2011. Effects of coral reef benthic primary producers on dissolved organic carbon and microbial activity. PLoS One 6:e27973.

75. Zotchev SB. 2013. Alkaloids from marine bacteria. Adv Bot Res 68:301-333.

76. Lozano GL, Park HB, Bravo JI, Armstrong EA, Denu JM, Stabb E V, Broderick NA, Crawford JM, Handelsman J. 2019. Bacterial analogs of plant tetrahydropyridine alkaloids mediate microbial interactions in a rhizosphere model system. Appl Environ Microbiol 85.

77. Othman L, Sleiman A, Abdel-Massih RM. 2019. Antimicrobial activity of polyphenols and alkaloids in middle eastern plants. Front Microbiol 10:911.

78. Kvennefors ECE, Sampayo E, Kerr C, Vieira G, Roff G, Barnes AC. 2012. Regulation of bacterial communities through antimicrobial activity by the coral holobiont. Microb Ecol 63:605-618.

79. Krediet CJ, Ritchie KB, Alagely A, Teplitski M. 2013. Members of native coral microbiota inhibit glycosidases and thwart colonization of coral mucus by an opportunistic pathogen. ISME J 7:980-990.

80. Shnit-Orland M, Kushmaro A. 2009. Coral mucus-associated bacteria: a possible first line of defense. FEMS Microbiol Ecol 67:371-380.

81. Yoch DC. 2002. Dimethylsulfoniopropionate: its sources, role in the marine food web, and biological degradation to dimethylsulfide. Appl Environ Microbiol 68:5804-5815.

82. Tripp HJ, Kitner JB, Schwalbach MS, Dacey JWH, Wilhelm LJ, Giovannoni SJ. 2008. SAR11 marine bacteria require exogenous reduced sulphur for growth. Nature 452:741744.

83. Deschaseaux ESM, Jones GB, Deseo MA, Shepherd KM, Kiene RP, Swan HB, Harrison PL, Eyre BD. 2014. Effects of environmental factors on dimethylated sulfur compounds and their potential role in the antioxidant system of the coral holobiont. Limnol Oceanogr 59:758-768.

84. Sunda W, Kieber DJ, Kiene RP, Huntsman S. 2002. An antioxidant function for DMSP and DMS in marine algae. Nature 418:317-320.

85. Yost DM, Jones RJ, Mitchelmore CL. 2010. Alterations in dimethylsulfoniopropionate (DMSP) levels in the coral Montastraea franksi in response to copper exposure. Aquat Toxicol 98:367-373.

86. Aguilar C, Raina J-B, Motti CA, Fôret S, Hayward DC, Lapeyre B, Bourne DG, Miller DJ. 2017. Transcriptomic analysis of the response of Acropora millepora to hypo-osmotic stress provides insights into DMSP biosynthesis by corals. BMC Genomics 18:1-14.

87. Broadbent AD, Jones GB, Jones RJ. 2002. DMSP in corals and benthic algae from the Great Barrier Reef. Estuar Coast Shelf Sci 55:547-555.

88. Raina J-B, Dinsdale EA, Willis BL, Bourne DG. 2010. Do the organic sulfur compounds DMSP and DMS drive coral microbial associations? Trends Microbiol 18:101-108.

89. Visscher PT, Taylor BF. 1994. Demethylation of dimethylsulfoniopropionate to 3mercaptopropionate by an aerobic marine bacterium. Appl Environ Microbiol 60:46174619.

90. Meikle P, Richards GN, Yellowlees D. 1988. Structural investigations on the mucus from six species of coral. Mar Biol 99:187-193.

91. Hadaidi G, Gegner HM, Ziegler M, Voolstra CR. 2019. Carbohydrate composition of mucus from scleractinian corals from the central Red Sea. Coral Reefs 38:21-27.

92. Wild C, Naumann M, Niggl W, Haas A. 2010. Carbohydrate composition of mucus 
released by scleractinian warm-and cold-water reef corals. Aquat Biol 10:41-45.

890 93. Lee STM, Davy SK, Tang SL, Kench PS. 2016. Mucus sugar content shapes the bacterial community structure in thermally stressed Acropora muricata. Front Microbiol 7:1-11.

94. Lee S, Davy SK, Tang S-L, Kench PS. 2016. Mucus sugar content shapes the bacterial community structure in thermally stressed Acropora muricata. Front Microbiol 7:371.

95. Wright RM, Strader ME, Genuise HM, Matz M. 2019. Effects of thermal stress on amount, composition, and antibacterial properties of coral mucus. PeerJ 7:e6849.

96. Smith SR, de Putron S, Murdoch TJT, Pitt JM, Nagelkerken I. 2013. Coral Reefs of the United Kingdom Overseas Territories 4:135-151.

97. Harwood CS, Parales RE. 1996. THE $\beta$-KETOADIPATE PATHWAY AND THE BIOLOGY OF SELF-IDENTITY. Annu Rev Microbiol 50:553-590.

98. Lu P, Wang W, Zhang G, Li W, Jiang A, Cao M, Zhang X, Xing K, Peng X, Yuan B. 2020. Isolation and characterization marine bacteria capable of degrading lignin-derived compounds. PLoS One 15:e0240187.

99. Martone PT, Estevez JM, Lu F, Ruel K, Denny MW, Somerville C, Ralph J. 2009. Discovery of lignin in seaweed reveals convergent evolution of cell-wall architecture. Curr Biol 19:169-175.

100. Kimes NE, Van Nostrand JD, Weil E, Zhou J, Morris PJ. 2010. Microbial functional structure of Montastraea faveolata, an important Caribbean reef-building coral, differs between healthy and yellow-band diseased colonies. Environ Microbiol 12:541-556.

101. Littman R, Willis BL, Bourne DG. 2011. Metagenomic analysis of the coral holobiont during a natural bleaching event on the Great Barrier Reef. Environ Microbiol Rep 3:651660 .

102. Richardson LL. 2004. Black band disease, p. 325-336. In Coral health and disease. Springer.

103. Sato Y, Civiello M, Bell SC, Willis BL, Bourne DG. 2016. Integrated approach to understanding the onset and pathogenesis of black band disease in corals. Environ Microbiol 18:752-765.

104. Kuta KG, Richardson LL. 2002. Ecological aspects of black band disease of corals: relationships between disease incidence and environmental factors. Coral Reefs 21:393398.

105. Jones R, Johnson R, Noyes T, Parsons R. 2012. Spatial and temporal patterns of coral black band disease in relation to a major sewage outfall. Mar Ecol Prog Ser 462:79-92.

106. Bourne DG, van der Zee MJJ, Botté ES, Sato Y. 2013. Sulfur-oxidizing bacterial populations within cyanobacterial dominated coral disease lesions. Environ Microbiol Rep 5:518-524.

107. Sato Y, Ling EYS, Turaev D, Laffy P, Weynberg KD, Rattei T, Willis BL, Bourne DG. 2017. Unraveling the microbial processes of black band disease in corals through integrated genomics. Sci Rep 7:1-14.

108. Meyer JL, Gunasekera SP, Scott RM, Paul VJ, Teplitski M. 2016. Microbiome shifts and the inhibition of quorum sensing by Black Band Disease cyanobacteria. ISME J 10:12041216.

109. Meyer B, Imhoff JF, Kuever J. 2007. Molecular analysis of the distribution and phylogeny of the soxB gene among sulfur-oxidizing bacteria-evolution of the Sox sulfur oxidation enzyme system. Environ Microbiol 9:2957-2977.

110. Denger K, Laue H, Cook AM. 1997. Thiosulfate as a metabolic product: the bacterial 
fermentation of taurine. Arch Microbiol 168:297-301.

111. Robbins SJ, Singleton CM, Chan CX, Messer LF, Geers AU, Ying H, Baker A, Bell SC, Morrow KM, Ragan MA, Miller DJ, Forêt S, Ball E, Beeden R, Berumen M, Aranda M, Ravasi T, Bongaerts P, Hoegh-Guldberg O, Cooke I, Leggat B, Sprungala S, Fitzgerald A, Shang C, Lundgren P, Fyffe T, Rubino F, van Oppen M, Weynberg K, Voolstra CR, Tyson GW, Bourne DG, Consortium R. 2019. A genomic view of the reef-building coral Porites lutea and its microbial symbionts. Nat Microbiol 4:2090-2100.

112. Lalucat J, Bennasar A, Bosch R, García-Valdés E, Palleroni NJ. 2006. Biology of Pseudomonas stutzeri. Microbiol Mol Biol Rev 70:510-547.

113. Rosenberg E, Zilber-Rosenberg I. 2018. The hologenome concept of evolution after 10 years. Microbiome 6:1-14.

114. Maynard J, Van Hooidonk R, Eakin CM, Puotinen M, Garren M, Williams G, Heron SF, Lamb J, Weil E, Willis B. 2015. Projections of climate conditions that increase coral disease susceptibility and pathogen abundance and virulence. Nat Clim Chang 5:688.

115. Muller EM, Bartels E, Baums IB. 2018. Bleaching causes loss of disease resistance within the threatened coral species Acropora cervicornis. Elife 7:e35066.

116. Heron SF, Maynard JA, Van Hooidonk R, Eakin CM. 2016. Warming trends and bleaching stress of the world's coral reefs 1985-2012. Sci Rep 6:38402.

117. Precht WF, Gintert BE, Robbart ML, Fura R, Van Woesik R. 2016. Unprecedented disease-related coral mortality in Southeastern Florida. Sci Rep 6:31374.

118. Damjanovic K, Blackall LL, Webster NS, van Oppen MJH. 2017. The contribution of microbial biotechnology to mitigating coral reef degradation. Microb Biotechnol.

119. Epstein HE, Smith HA, Torda G, van Oppen MJH. 2019. Microbiome engineering: enhancing climate resilience in corals. Front Ecol Environ 17:100-108. 
Figures
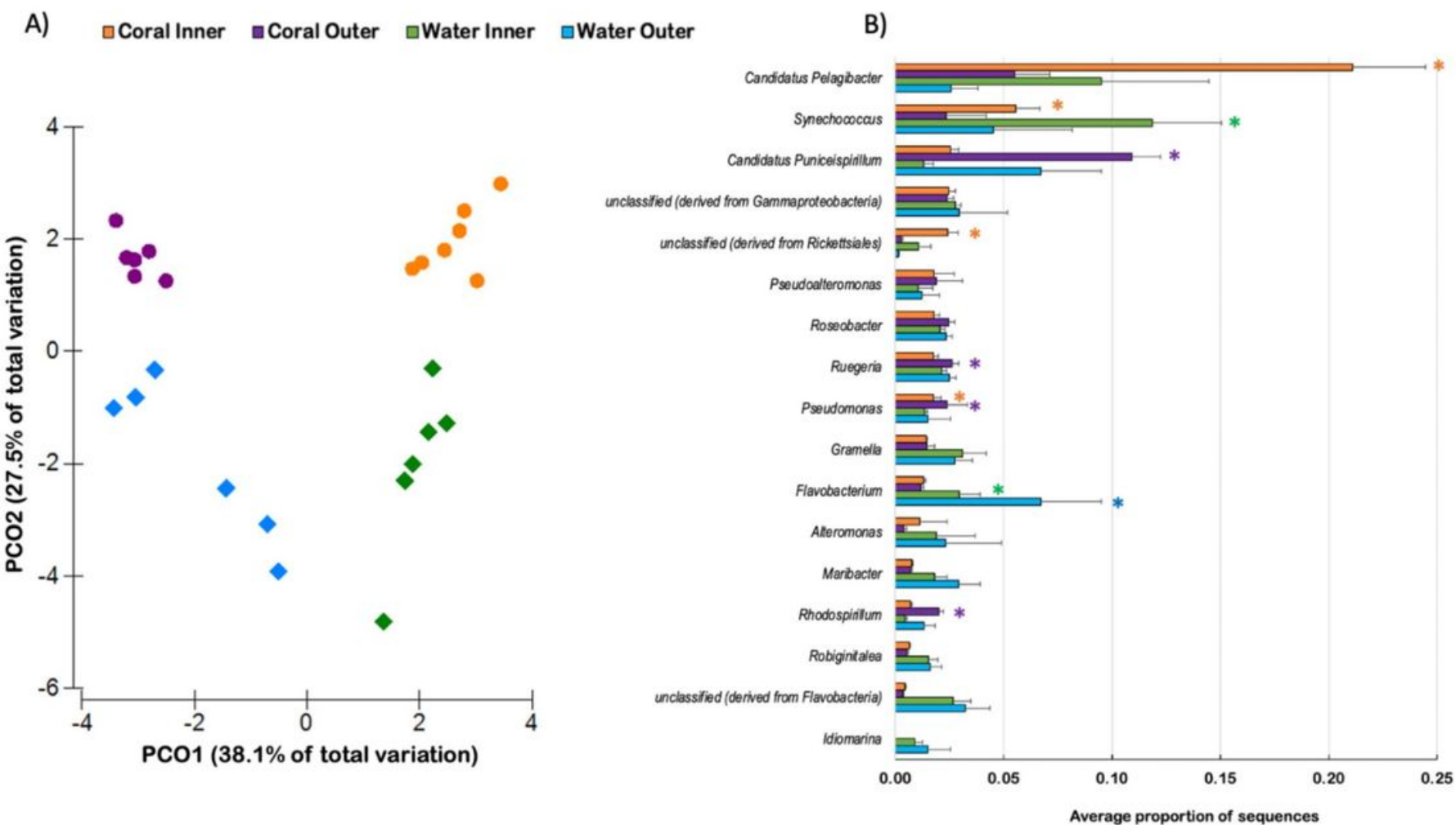

Figure 1

Please see the Manuscript PDF file for the complete figure caption

\section{Image not available with this version}

Figure 2

Please see the Manuscript PDF file for the complete figure caption 

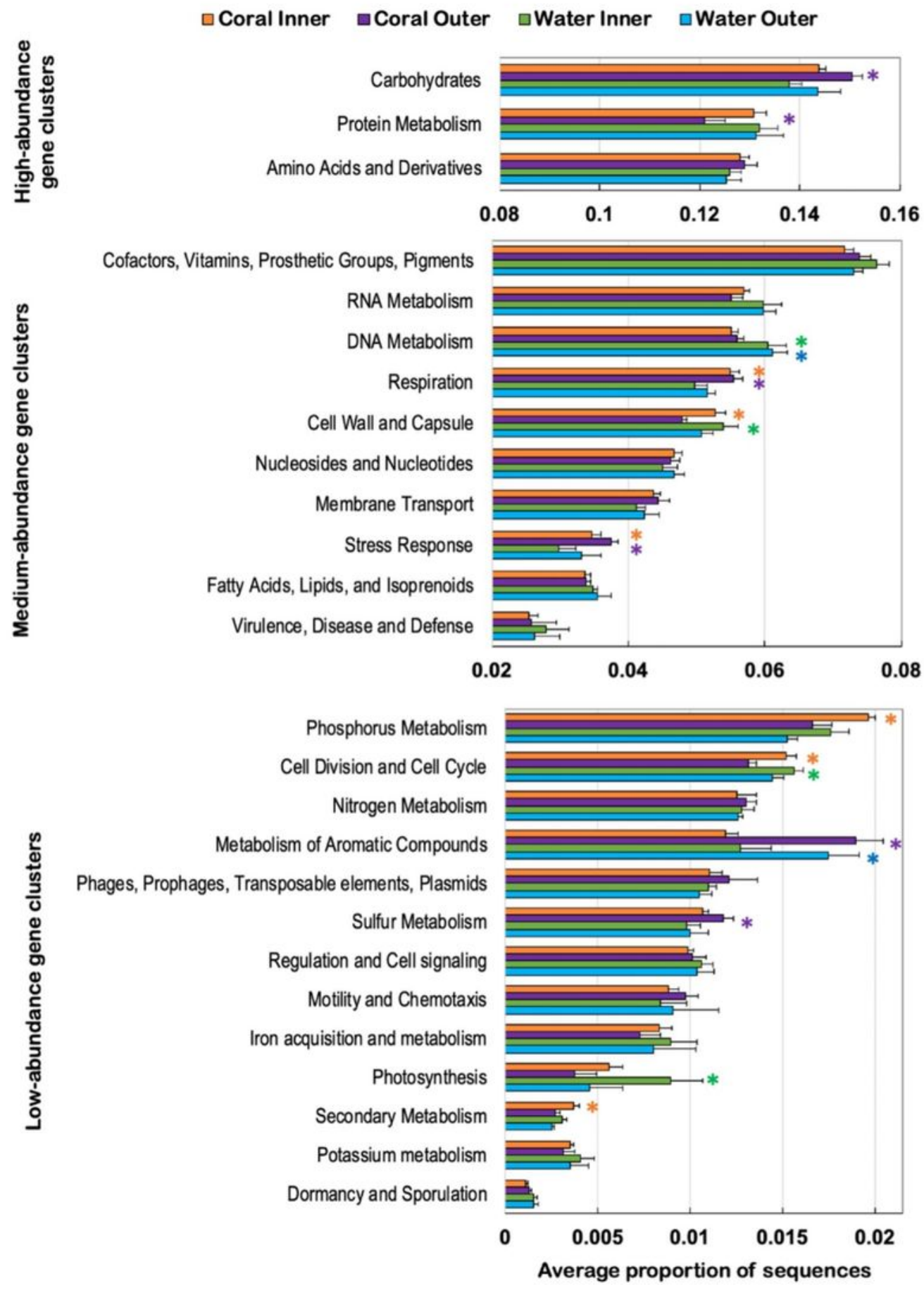

Figure 3

Please see the Manuscript PDF file for the complete figure caption 
A)

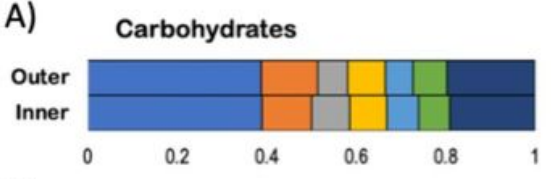

B) Protein metabolism

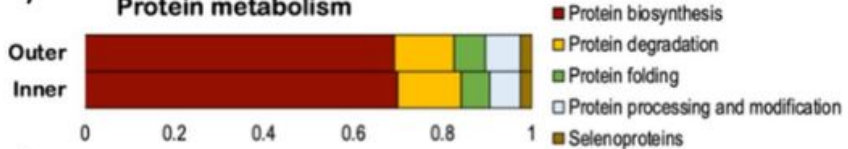

C)

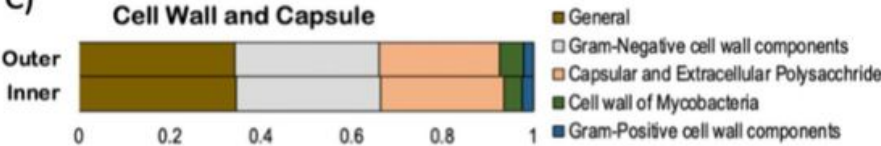

D)

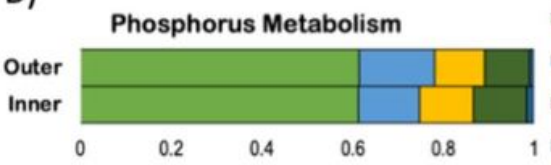

aPhosphate metabolism

a Phosphate transporter and control of PHC regulon $\mathrm{P}$ uptake by Cyanobacteria

1 alkylphosphonate ublization

E)

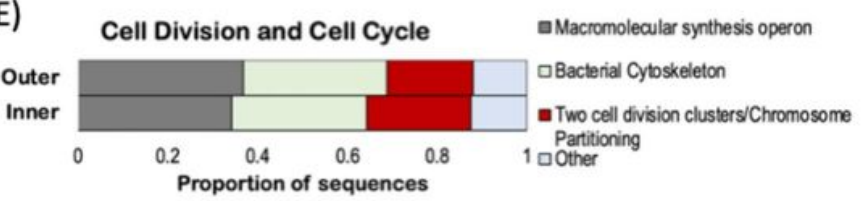

F) Metabolism of Aromatic Compounds

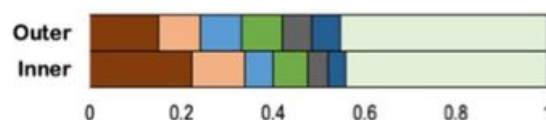

0.4

G)

Outer

Photosynthesis

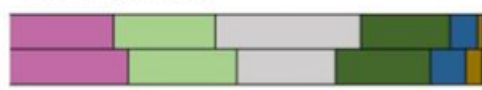

0

0.4

0.6

0.8
H) Secondary Metabolism

Outer

Inner

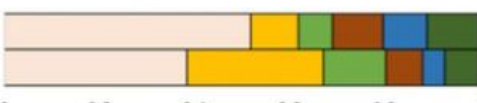

n-Phenylalkanoic acid decradation Anaerobic benzoate metabolism a Phenylacety-COA catabolic pathway (core) a Catechol branch of beta-ketoadipate pathway a Phenylpropanoid compound degradation

- Benzoate catabolism a Other

Sulfur Metabolism

Outer

Inner

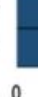

aPhotosystem II

aPhycobilisome

aProteorhodopsin

aPhotosystem I

- Photosystem II-type photosynthetic reaction center

aBacteriorhodopsin a Light-harvesting complexes

$\square$ Auxin biosynthesis

aAlkabid biosynthesis from L-yysine

aSteroid sulfates

- Auxin degradaton

- Cinnamic Acid Degradaton

1 ather

- Inorganic Sullur Assimilation - Organic Sulfur Assimilation 口DMSP breakdown - Sulfur Oxidation aOther

\section{Figure 4}

Please see the Manuscript PDF file for the complete figure caption 
A)

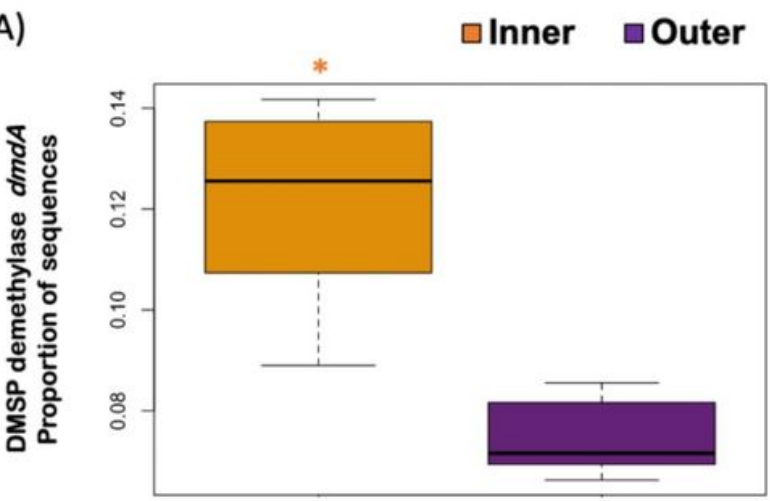

C)

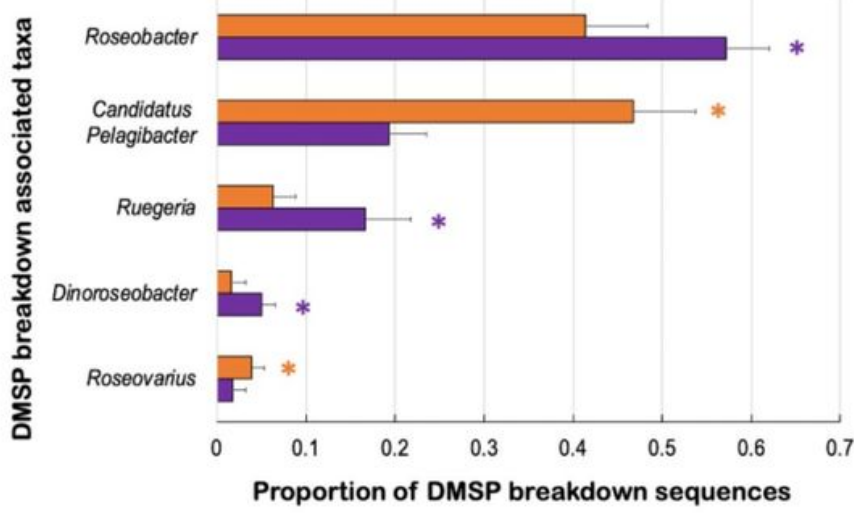

B)

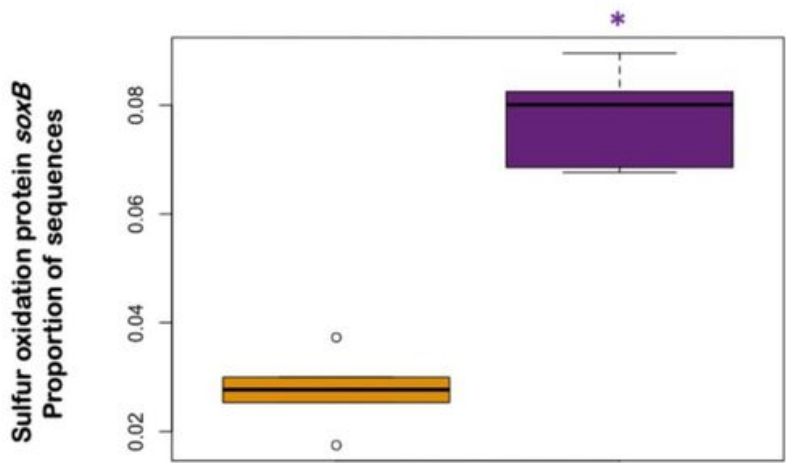

D)

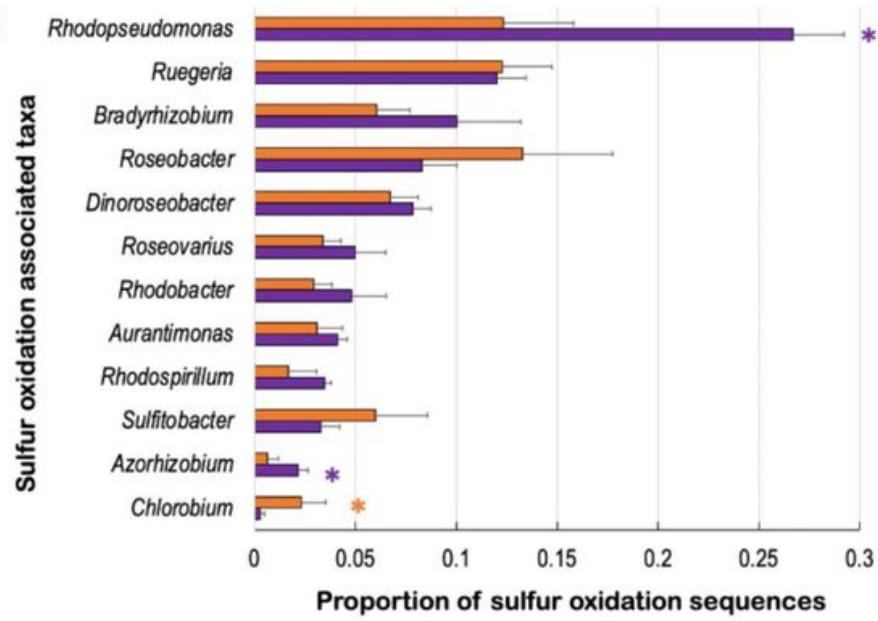

Figure 5

Please see the Manuscript PDF file for the complete figure caption

Fluctuating environment (Inner Reefs)

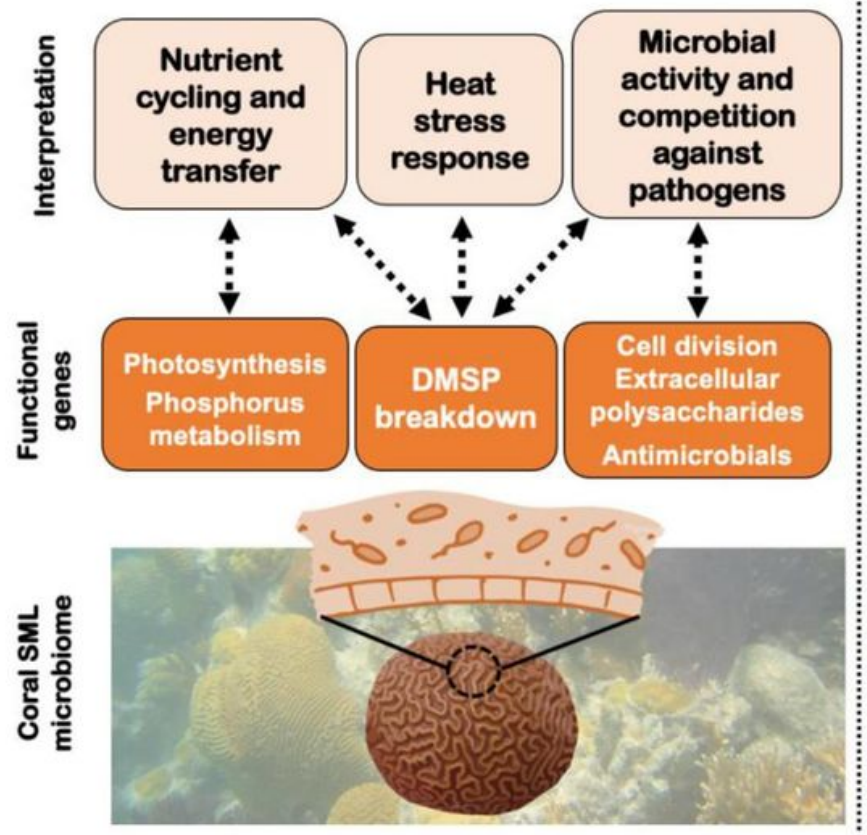

\section{Stable environment (Outer Reefs)}
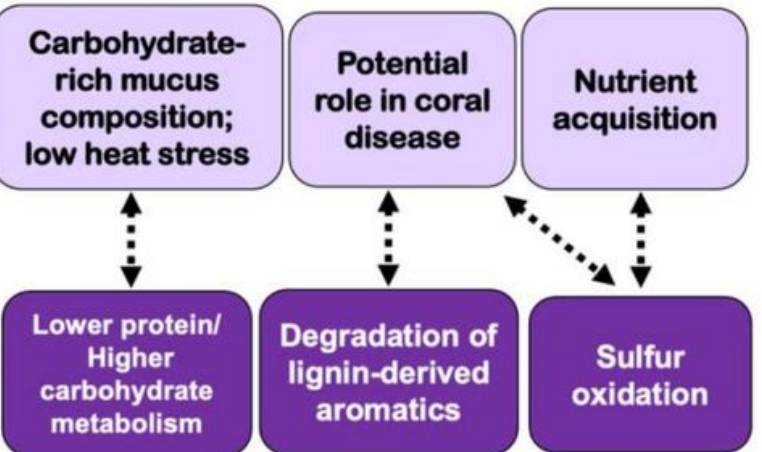

Degradation of

lignin-derived

aromatics

Sulfur

oxidation

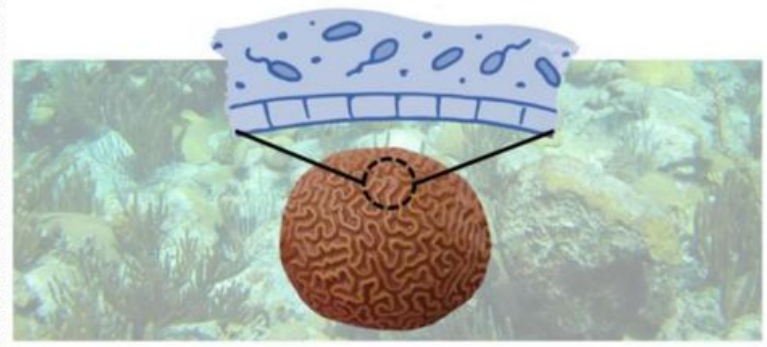


Figure 6

Please see the Manuscript PDF file for the complete figure caption

\section{Supplementary Files}

This is a list of supplementary files associated with this preprint. Click to download.

- S1.jpg 